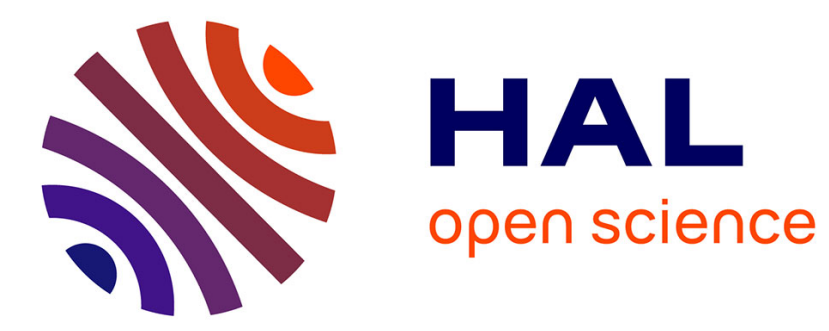

\title{
Chemical weathering and consumption of atmospheric carbon dioxide in the Alpine region
}

Marco Donnini, Francesco Frondini, Jean-Luc Probst, Anne Probst, Carlo Cardellini, Ivan Marchesini, Fausto Guzzetti

\section{- To cite this version:}

Marco Donnini, Francesco Frondini, Jean-Luc Probst, Anne Probst, Carlo Cardellini, et al.. Chemical weathering and consumption of atmospheric carbon dioxide in the Alpine region. Global and Planetary Change, 2016, vol. 136, pp. 65-81. 10.1016/j.gloplacha.2015.10.017 . hal-01252822

\section{HAL Id: hal-01252822 \\ https://hal.science/hal-01252822}

Submitted on 8 Jan 2016

HAL is a multi-disciplinary open access archive for the deposit and dissemination of scientific research documents, whether they are published or not. The documents may come from teaching and research institutions in France or abroad, or from public or private research centers.
L'archive ouverte pluridisciplinaire HAL, est destinée au dépôt et à la diffusion de documents scientifiques de niveau recherche, publiés ou non, émanant des établissements d'enseignement et de recherche français ou étrangers, des laboratoires publics ou privés. 


\section{OATAO}

\section{Open Archive TOULOUSE Archive Ouverte (OATAO)}

OATAO is an open access repository that collects the work of Toulouse researchers and makes it freely available over the web where possible.

This is an author-deposited version published in : http://oatao.univ-toulouse.fr/ Eprints ID : 14623

To link to this article : DOI:10.1016/j.gloplacha.2015.10.017 URL : http://dx.doi.org/10.1016/j.gloplacha.2015.10.017

To cite this version : Donnini, Marco and Frondini, Francesco and Probst, Jean-Luc and Probst, Anne and Cardellini, Carlo and Marchesini, Ivan and Guzzetti, Fausto Chemical weathering and consumption of atmospheric carbon dioxide in the Alpine region. (2016) Global and Planetary Change, vol. 136. pp. 65-81. ISSN 09218181

Any correspondance concerning this service should be sent to the repository administrator: staff-oatao@,listes-diff.inp-toulouse.fr 


\title{
Chemical weathering and consumption of atmospheric carbon dioxide in the Alpine region
}

\author{
Marco Donnini ${ }^{\mathrm{a}, \mathrm{d}, *}$, Francesco Frondini ${ }^{\mathrm{a}}$, Jean-Luc Probst ${ }^{\mathrm{b}, \mathrm{c}}$, Anne Probst ${ }^{\mathrm{b}, \mathrm{c}}$, Carlo Cardellini ${ }^{\mathrm{a}}$, \\ Ivan Marchesini ${ }^{\mathrm{d}}$, Fausto Guzzetti ${ }^{\mathrm{d}}$ \\ a Università degli Studi di Perugia, Dipartimento di Fisica e Geologia, Perugia, Italy \\ ${ }^{\mathrm{b}}$ University of Toulouse, INPT, UPS, Laboratorie Ecologie Fonctionnelle et Environment (EcoLab), ENSAT, Castanet Tolosan, France \\ c Centre National de la Recherche Scientifique (CNRS), EcoLab, ENSAT, Castanet Tolosan, France \\ d Consiglio Nazionale delle Ricerche (CNR), Istituto di Ricerca per la Protezione Idrogeologica, Perugia, Italy
}

\section{A R T I C L E I N F O}

\section{Article history:}

Received 25 May 2015

Received in revised form 26 September 2015

Accepted 30 October 2015

Available online 31 October 2015

\section{Keywords:}

Chemical weathering

Carbon dioxide

Alps

Rivers

Runoff

\begin{abstract}
A B S T R A C T
To determine the $\mathrm{CO}_{2}$ consumption due to chemical weathering in the Alps, water samples from the 32 main Alpine rivers were collected and analysed in two periods, spring 2011 and winter 2011/2012. Most of the river waters are characterized by a bicarbonate earth-alkaline composition with some samples showing a clear enrichment in sulphates and other samples showing a slight enrichment in alkaline metals. The amount of total dissolved solids (TDS) ranges between 96 and $551 \mathrm{mg} / \mathrm{L}$. Considering the major ion composition and the $\mathrm{Sr}$ isotopic composition of water samples, coherently with the geological setting of the study area, three major reservoirs of dissolved load have been recognized: carbonates, evaporites and silicates. Based on a chemical mass balance, the flux of dissolved solids, and the flux of carbon dioxide consumed by chemical weathering have been computed for each basin and for the entire study area. Results show that the flux of dissolved solids, ranges from $8 \times 10^{3}$ to $411 \times 10^{3} \mathrm{~kg} \mathrm{~km}^{-2} \mathrm{y}^{-1}$, with an average value of $127 \times 10^{3} \mathrm{~kg} \mathrm{~km}^{-2} \mathrm{y}^{-1}$, while the flux of carbon dioxide consumed by chemical weathering in the short-term $(<1 \mathrm{Ma})$ is $5.03 \times 10^{5} \mathrm{~mol} \mathrm{~km}^{-2} \mathrm{y}^{-1}$ 1 on average. Since part of the $\mathrm{CO}_{2}$ is returned to the atmosphere through carbonate precipitation and reverse weathering once river water reaches the ocean, the $\mathrm{CO}_{2}$ removed from the atmosphere/soil system in the long-term $(>1 \mathrm{Ma})$ is much smaller than the $\mathrm{CO}_{2}$ consumed in the short-term and according to our calculations amounts to $2.01 \times 10^{4} \mathrm{~mol} \mathrm{~km}{ }^{-2} \mathrm{y}^{-1}$ on average. This value is almost certainly a minimum estimate of the total amount of $\mathrm{CO}_{2}$ fixed by weathering on the long-term because in our calculations we assumed that all the alkaline metals deriving from rock weathering in the continents are rapidly involved in the process of reverse weathering in the oceans, while there are still large uncertainties on the magnitude and significance of this process. The values of $\mathrm{CO}_{2}$ flux consumed by weathering are strongly correlated with runoff while other potential controlling factors show only weak correlations or no correlation. Our estimation of the $\mathrm{CO}_{2}$ consumed by weathering in the Alpine basins is in the same order of magnitude, but higher than the world average and is consistent with previous estimations made in river basins with similar climatic conditio and similar latitudes.
\end{abstract}

\section{Introduction}

Carbon is continuously cycled among oceans, atmosphere, ecosystems, and geosphere (Holland, 1978; Berner, 2003; Kump et al., 2009). Considering the time scale of the phenomena, longer or shorter than one million years, it is possible to distinguish the "short-term" carbon cycle and the "long-term" carbon cycle. In the "short-term" carbon cycle, carbon is exchanged mainly within the superficial systems (atmosphere, oceans, biota, soil, and anthropogenic $\mathrm{CO}_{2}$ production). Over the "long-term", carbon is involved in slow exchanges between the solid Earth and the ocean-atmosphere system, and the concentration of

\footnotetext{
* Corresponding author at: CNR-IRPI, Via Madonna Alta, 126, CAP 06128 Perugia, Italy. E-mail address: marco.donnini@irpi.cnr.it (M. Donnini).
}

atmospheric carbon dioxide derives primarily from the balance between $\mathrm{CO}_{2}$ uptake by chemical weathering and $\mathrm{CO}_{2}$ release by magmatismmetamorphism (Berner et al., 1983; Berner, 1991, 1994; Berner and Kothavala, 2001; Berner, 2004, 2006; Gislason and Oelkers, 2011; Li and Elderfield, 2013).

Chemical weathering is a key process for understanding the global carbon cycle, both on long and short-terms (Brady, 1991; Kump et al., 2000; White, 2003; Kump et al., 2009; Tipper et al., 2006), and chemical weathering rates are complex functions of many factors including dissolution kinetics of minerals (Brantley, 2003), mechanical erosion (Pinet and Souriau, 1988), lithology (Basu, 1981; Amiotte-Suchet and Probst, 1993a; Amiotte-Suchet and Probst, 1993b; Bluth and Kump, 1994), tectonics (Hren et al., 2007; Dixon et al., 2012; Li et al., 2009), biota (Knoll and James, 1987; Schwartzman and Volk, 1989; Drever, 1994; Berner 
et al., 2003), climate (Fournier, 1960; Walker et al., 1981; Bluth and Kump, 1994), hydrology (Tardy, 1986; Berner and Berner, 1987; Amiotte-Suchet and Probst, 1993b; Velbel, 1993), and various human activities (Flintrop et al., 1996; Yang et al., 1996).

Solutes produced by chemical weathering on the continents are carried to the oceans by rivers. Therefore, the composition of river water is a good indicator of chemical weathering processes (Mackenzie and Garrels, 1966; Garrels and Mackenzie, 1971; Meybeck, 1987; Tardy, 1986; Probst, 1992; Gaillardet et al., 1999; Viers et al., 2007; Berner and Berner, 2012), and the flux of solutes is an indirect measure of the transfer of carbon from the atmosphere to the terrestrial rocks. In fact, given that carbonate and silicate weathering needs atmospheric and soil $\mathrm{CO}_{2}$ to occur, the evaluation of the weathering rates, that is the knowledge of the dissolved loads transported from the continents to the oceans, allows for an indirect estimation of the atmospheric $\mathrm{CO}_{2}$ consumed by weathering. Under this perspective, the study of the elemental fluxes due to present day chemical weathering is necessary to understand the past and to make reliable models about the future trends of the global carbon cycle (Brady, 1991; Millot et al., 2002; Beaulieu et al., 2012).

The study of chemical weathering is based on two complementary approaches, namely (i) small scale studies of river basins characterized by a single lithology (Amiotte-Suchet and Probst, 1993b; Bluth and Kump, 1994; White and Blum, 1995; Gislason et al., 1996; Louvat and Allègre, 1997), and (ii) global scale studies based on data from large rivers (Berner et al., 1983; Meybeck, 1987, 2003; Probst et al., 1994; Amiotte-Suchet, 1995; Amiotte-Suchet and Probst, 1995; Boeglin and Probst, 1998; Gaillardet et al., 1999; Mortatti and Probst, 2003). Small scale studies can give detailed data on the weathering rates of a specific rock type under a given climate, while large scale studies can provide global data, integrating the contributions of large portions of continental crust and different climatic regions.

Gaillardet et al. (1999), using an inverse modelling approach based on the river water chemistry and $\mathrm{Sr}$ isotopic composition, calculated the weathering rates and the fluxes of $\mathrm{CO}_{2}$ consumed by rock weathering for the basins of the 60 largest rivers of the world, computing a world average $\mathrm{CO}_{2}$ consumption due to chemical weathering of $246 \mathrm{~mol} \mathrm{~km}^{-2} \mathrm{y}^{-1}$. Three of the rivers considered in Gaillardet et al. (1999) drain the Alpine chain (i.e., Rhine, Rhone, and Po) and are characterized by $\mathrm{CO}_{2}$ consumption rates two to five times higher than the world average. Considering the variability of rocks and soils that characterizes the region, the Alpine chain can be considered a model location to study the present-day atmospheric $\mathrm{CO}_{2}$ consumption over a large region.

In this work, we present a detailed study of the dissolved loads transported by the 32 main Alpine rivers, in order to (i) estimate the present-day weathering rates and the related atmospheric and soil $\mathrm{CO}_{2}$ consumption for the entire Alpine region, (ii) compare our results with the data of earlier works, (iii) evaluate the relative importance of carbonate and silicate weathering both on short and long-term global carbon cycle, and (iv) determine the main environmental and geological parameters controlling the weathering rates and the $\mathrm{CO}_{2}$ consumption in the Alps.

Starting from the chemical composition of river waters, the amount of $\mathrm{CO}_{2}$ consumed by rock weathering has been modelled using a multidisciplinary approach based on the MEGA geochemical code (Major Element Geochemical Approach - Amiotte-Suchet, 1995; Amiotte-Suchet and Probst, 1995, 1996), a GIS based hydrologic and geologic study, and an isotopic study.

\section{Study area}

The Alps (south-Central Europe) are a collisional belt generated by the convergence of the African and European plates and the consequent closure of the ocean basin located in the Mediterranean region during Cretaceous to present (Trümphy, 1960; Frisch, 1979; Tricart, 1984; Haas et al., 1995; Stampfly et al., 2001; Dal Piaz et al., 2003).
The Alps are characterized by an arc shape and extend, west to east, from the Gulf of Genova to Wien (Fig. 1). South of Genova, the Alpine range disappears, as it was fragmented during the Late Neogene by the opening of the Tyrrenian basin. Here the Alps are partially continuous to the Apennine chain. To the east, the former connection between the Alpine and Carpathian belts is buried below the Neogene fill of the Wien and Styria (Pannonian) basin. North of Alps is located the Molasse Basin (a Cenozoic foredeep basin) that extends from France to the eastern border of Austria. Other major Cenozoic basins are the Rhône Graben to the west, and the Po Plain to the south.

According to the direction of tectonic transport, the Alps (Fig. 1) may be subdivided into two belts of different size, age, and geological characteristics (Dal Piaz et al., 2003): (1) the Europe-vergent belt, a thick collisional wedge of Cretaceous-Neogene age, consisting of continental and minor oceanic units radially displaced towards the Molasse foredeep and the European foreland, (2) the Southern Alps, a shallower (nonmetamorphic) and younger (Neogene) thrust-and-fold belt displaced to the south (Adria-vergent), which developed within the Alpine hinterland of the Adriatic upper plate, far from the oceanic suture. The Periadriatic Line, a major fault system of Oligocene-Neogene age, separates these belts. The various segments of the Periadriatic Line take various names, from west to east, the Canavese, Insubric, Giudicarie, Pusteral and Gaital lines (Dal Piaz et al., 2003; Schmid et al., 2004).

From a hydrological point of view, the Alps contribute significantly to the total discharge of the major European rivers, most of which have their headwaters in the Alps and transport the Alpine waters to lower-lying areas. The Alps are crucial for water accumulation and water supply, and therefore they are often referred to as a natural "water towers" (Viviroli and Weingartner, 2004).

Water resources in the Alps are stored in glaciers (in the Alps, around 5150 glaciers presently cover about $2909 \mathrm{~km}^{2}$, approximately $1.5 \%$ of the total area of the Alps), lakes, groundwater reservoirs, and soils. The Alps represent an enormous natural water reservoir since precipitation in winter is retained as snow and ice. Considerable quantities of water can be accumulated and released through the summer melting of glaciers and snow, thus providing water during the dry season when precipitation and runoff are often least in the lowlands, and demands are highest. Particularly, this becomes effective in the dry months of late summer, when the Alps play a distinct supportive role with regard to overall discharge. This natural storage mechanism benefits many river systems in Europe, including the four major alpine rivers, the Rhine, the Danube, the Po, and the Rhône.

A comparison between the proportion of discharge that can be expected on the basis of the catchment size and the actual discharge measured demonstrates the hydrological significance of the Alps that, with a mean contribution ranging from 26\% (Danube) to 53\% (Po) of the total discharge, supply up to 2-6 times more water than might be expected on the basis of the catchment size (Weingartner et al., 2007).

Generally the Alpine rivers have a maximum flow rate in July, and a minimum rate in January. This is because the runoff of Alpine catchments is influenced by glacier melt, snow accumulation, and snowmelt (Gurtz et al., 1999; Verbunt et al., 2003).

\section{Materials and methods}

\subsection{Theoretical background}

The dissolved load of streams originates from atmospheric input, pollution, evaporite dissolution, and weathering of carbonate and silicate rocks. The application of mass balance calculations allows for the quantification of the different contributions (Bricker and Jones, 2003). The quantification of the carbonate and silicate components of dissolved load is essential for the evaluation of the atmospheric/soil $\mathrm{CO}_{2}$ consumed by rock weathering. In fact, the weathering reactions of silicate mineral hydrolysis and dissolution of carbonates consume atmospheric/soil carbon dioxide and produce an increase of alkalinity 


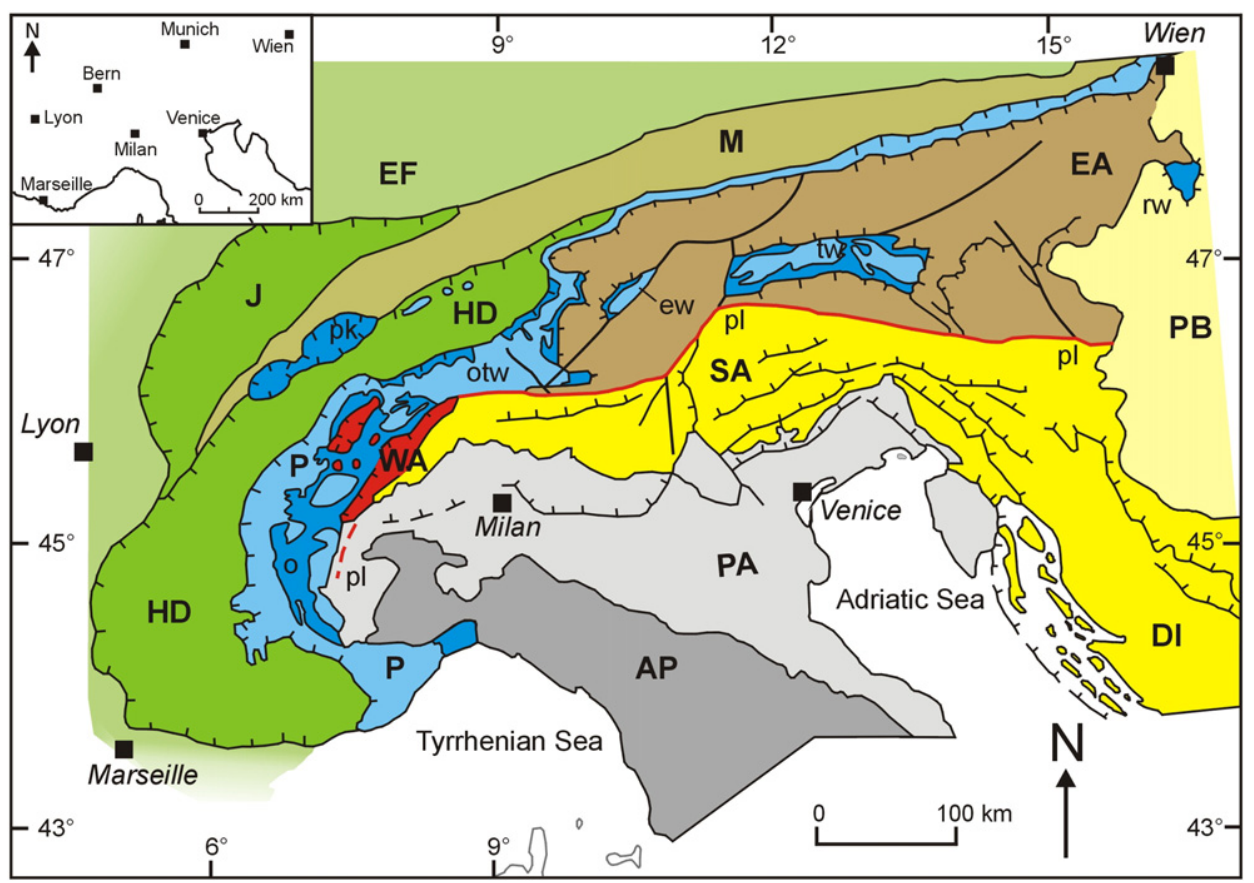

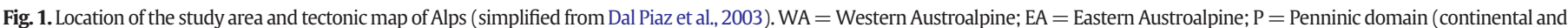

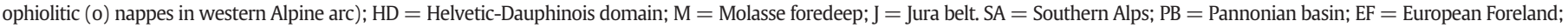

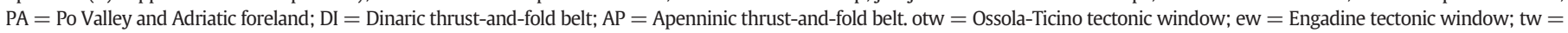
Tauern tectonic window; rw $=$ Rechnitz tectonic window; $\mathrm{Pk}=$ Prealpine klippen; $\mathrm{pl}=$ periadriatic lineament.

of the solutions (Mortatti and Probst, 2003), as shown by the following reactions:

albite into kaolininite,

$2 \mathrm{NaAlSi}_{3} \mathrm{O}_{8}+2 \mathrm{CO}_{2}+11 \mathrm{H}_{2} \mathrm{O} \rightarrow \mathrm{Al}_{2} \mathrm{Si}_{2} \mathrm{O}_{5}(\mathrm{OH})_{4}+2 \mathrm{HCO}_{3}^{-}+2 \mathrm{Na}^{+}$

$+4 \mathrm{H}_{4} \mathrm{SiO}_{4}$

K-feldspar into montmorillonite,

$2 \mathrm{KAlSi}_{3} \mathrm{O}_{8}+2 \mathrm{CO}_{2}+6 \mathrm{H}_{2} \mathrm{O} \rightarrow \mathrm{Al}_{2} \mathrm{Si}_{4} \mathrm{O}_{10}(\mathrm{OH})_{2}+2 \mathrm{HCO}_{3}^{-}+2 \mathrm{~K}^{+}$

$+2 \mathrm{H}_{4} \mathrm{SiO}_{4}$

Ca-plagioclase into kaolinite,

$\mathrm{CaAl}_{2} \mathrm{Si}_{2} \mathrm{O}_{8}+2 \mathrm{CO}_{2}+3 \mathrm{H}_{2} \mathrm{O} \rightarrow \mathrm{Al}_{2} \mathrm{Si}_{2} \mathrm{O}_{5}(\mathrm{OH})_{4}+2 \mathrm{HCO}_{3}^{-}+\mathrm{Ca}^{++}$

olivine weathering,

$\mathrm{Mg}_{2} \mathrm{SiO}_{4}+4 \mathrm{CO}_{2}+4 \mathrm{H}_{2} \mathrm{O} \rightarrow 2 \mathrm{Mg}^{++}+4 \mathrm{HCO}_{3}^{-}+\mathrm{H}_{4} \mathrm{SiO}_{4}$

calcite dissolution,

$\mathrm{CaCO}_{3}+\mathrm{CO}_{2}+\mathrm{H}_{2} \mathrm{O} \rightarrow \mathrm{Ca}^{++}+2 \mathrm{HCO}_{3}^{-}$

dolomite dissolution,

$\mathrm{CaMg}\left(\mathrm{CO}_{3}\right)_{2}+2 \mathrm{CO}_{2}+2 \mathrm{H}_{2} \mathrm{O} \rightarrow \mathrm{Ca}^{++}+\mathrm{Mg}^{++} 4 \mathrm{HCO}_{3}^{-}$.

For each process, the moles of atmospheric/soil $\mathrm{CO}_{2}$ consumed by the weathering of one mole of mineral can be computed from the stoichiometry of the reactions.

Not all the consumed $\mathrm{CO}_{2}$ is permanently removed from the atmosphere because part of the carbon is returned to the atmosphere through several processes. On time scales longer than $1 \mathrm{Ma}$, the $\mathrm{CO}_{2}$ consumed by weathering of carbonates in the continents is returned completely to the atmosphere when carbonate minerals precipitate in the ocean (reverse of reactions (5) and (6)). Half of the $\mathrm{CO}_{2}$ consumed during weathering of $\mathrm{Ca}$ and $\mathrm{Mg}$ silicates (reactions (3) and (4)) is precipitated as $\mathrm{CaCO}_{3}$ after transportation of $\mathrm{Ca}^{++}$and $\mathrm{HCO}_{3}^{-}$in the ocean, and half is released back into the atmosphere as $\mathrm{CO}_{2}$ (reverse of reactions (5) and (6)). Finally, the role of $\mathrm{Na}$ and $\mathrm{K}$ silicates poses some uncertainty. In fact even if their weathering reactions consume $\mathrm{CO}_{2}$ (reactions (1) and (2)), once the $\mathrm{Na}^{+}$and $\mathrm{K}^{+}$ions transported by rivers reach the ocean, they may undergo reverse weathering to form authigenic clays and $\mathrm{CO}_{2}$ (Huh, 2010).

As a result, on the long-term (more than $1 \mathrm{Ma}$ ), only weathering of $\mathrm{Ca}$ and $\mathrm{Mg}$ silicate minerals is a net sink for atmospheric/soil $\mathrm{CO}_{2}$ (Huh, 2010; Berner et al., 1983), while on shorter time-scales also the alteration of $\mathrm{Na}$ and $\mathrm{K}$ silicates and the dissolution of $\mathrm{Ca}$ and $\mathrm{Mg}$ carbonates act as temporary sinks for atmospheric/soil $\mathrm{CO}_{2}$.

For these reasons, we considered two different mass balance equations. On time-scales shorter than 1 million year (short-term carbon cycle), the total atmospheric/soil $\mathrm{CO}_{2}$ flux ( $\left.F_{\mathrm{CO} 2 \text {-short }}\right)$ consumed by rock weathering on a river basin can be calculated by the following equation:

$$
\begin{aligned}
F_{\mathrm{CO} 2-\text { short }}= & F_{\mathrm{Na}-\text { sil }}+F_{\mathrm{K}-\text { sil }}+2 F_{\mathrm{Mg}-\text { sil }}+F_{\mathrm{Mg}-\text { carb }}+2 F_{\mathrm{Ca}-\text { sil }} \\
& +F_{\mathrm{Ca}-\text { carb }}
\end{aligned}
$$

for time-scales longer than 1 million years (long-term carbon cycle), considering the return of $\mathrm{CO}_{2}$ to the atmosphere related to carbonate precipitation and reverse weathering, the net flux of $\mathrm{CO}_{2}\left(F_{\mathrm{CO} 2 \text {-long }}\right)$ is given by:

$F_{\text {CO2-long }}=F_{\mathrm{Mg} \text {-sil }}+F_{\mathrm{Ca}-\text { sil }}$

where $F_{\mathrm{X}}$ is the flux of a generic chemical species $\mathrm{X}$, given by its molal concentration multiplied by the river flow rate, and the suffixes sil and carb indicate if the considered chemical species derives from silicate or carbonate weathering (for example $F_{\mathrm{Mg} \text {-sil }}$ means flux of $\mathrm{Mg}$ deriving from silicate weathering). The factor 1 for $F_{\mathrm{Na} \text {-sil }}, F_{\mathrm{K} \text {-sil }}, F_{\mathrm{Mg} \text {-carb }}, F_{\mathrm{Ca}-\text { carb }}$ in Eq. (7) and $F_{\mathrm{Mg} \text {-sil }} F_{\mathrm{Ca}-\text { sil }}$ in Eq. (8) or 2 for $F_{\mathrm{Mg} \text {-sil }} F_{\mathrm{Ca} \text {-sil }}$ in Eq. (7) derive from the stoichiometric coefficients of the considered weathering reactions (Eqs. (1)-(6)). 
Eqs. (7) and (8) are applicable if the following assumptions are valid: (i) carbonic acid is the only source of protons in the weathering reactions (the contribution of other acids like $\mathrm{HNO}_{3}$, $\mathrm{H}_{2} \mathrm{SO}_{4}$ is negligible); (ii) the main chemical reactions occurring in the river basins are congruent dissolution of calcite, dolomite and olivine and incongruent dissolution of albite and K-feldspar into kaolinite and of anorthite into montmorillonite; and (iii) pyrite dissolution, producing acidic waters, is negligible.

Further assumptions were considered for the calculation of $F_{\mathrm{CO} 2-l o n g}$. These assumptions imply that the value computed with Eq. (8) is just a rough (probably minimum) estimation of the $\mathrm{CO}_{2}$ permanently removed from the atmosphere. The assumption that all the $\mathrm{CO}_{2}$ consumed by carbonate dissolution is completely returned to the atmosphere in $1 \mathrm{Ma}$ is widely accepted, and is coherent with the residence time of $\mathrm{Ca}$ in the ocean system $(1 \mathrm{Ma})$. In fact, a small part of $\mathrm{Ca}^{++}$from rivers is not removed by carbonate precipitation but is precipitated as anhydrite or gypsum without any $\mathrm{CO}_{2}$ production (Mackenzie and Garrels, 1966; Emerson and Hedges, 2008), but presently this amount is very small compared to carbonate production, except for very peculiar environments. Larger uncertainties pertain to the role of reverse weathering. This process, by which new clays are formed by chemical combination of elemental material from oceans and marine sediments (Mackenzie and Kump, 1995), has been hypothesised on a thermodynamic basis to explain the apparent imbalance between weathering and marine $\mathrm{CaCO}_{3}$ precipitation in the oceans (Mackenzie and Garrels, 1966; Sillen, 1967), but has little experimental evidence (Emerson and Hedges, 2008). According to Holland (1978), only a small fraction (10-20\%) of the clay minerals delivered to the oceans by rivers undergo authigenesis, but recent field and experimental studies (Michalopoulos and Aller, 1995, 2004) have shown that rapid formation of authigenic clay minerals is plausible under certain conditions, and the role of reverse weathering has been revaluated (Li and Elderfield, 2013; Misra and Froelich, 2012). Further sources of uncertainty, could be the role of sulphide oxidation in carbonate dissolution (Torres et al., 2014) and hydrothermal alteration reactions in the ocean.

\subsection{Estimation of the $\mathrm{CO}_{2}$ flux consumed by weathering}

For the estimation of the $\mathrm{CO}_{2}$ flux consumed by weathering in the Alps, we first defined the drainage basins of the main Alpine rivers (Fig. 2) and their hydrologic, geographic, and geologic features (precipitations, mean elevation, drainage basin area, and surface area of the main rock types cropping out in the basin) using a GIS based approach. Next, the selected rivers were sampled near the basin outlets during dry and flood seasons. Then, we applied a revised version of the MEGA (Major Element Geochemical Approach) geochemical code (Amiotte-Suchet, 1995; Amiotte-Suchet and Probst, 1996) to the chemical compositions of the selected rivers in order to discriminate the different components of dissolved load, and to quantify the atmospheric $\mathrm{CO}_{2}$ consumed by weathering in the Alpine region. The approach was successfully applied to the Congo, Amazon, and Niger River basins (Probst et al., 1994; Boeglin and Probst, 1998; Mortatti and Probst, 2003).

The complete calculation procedure consists of several steps:

First, subtraction of the rain contribution to the river waters composition knowing the $\mathrm{X} / \mathrm{Cl}$ molal ratios of rainwater in the study area $(\mathrm{X}=$ $\mathrm{Na}, \mathrm{K}, \mathrm{Mg}, \mathrm{Ca}$ ). In this study we applied a further correction subtracting the anthropogenic contribution when it was present. The correction for the anthropogenic contribution is based on the consideration that an excess of $\mathrm{Cl}$ with respect to the $\mathrm{Na} / \mathrm{Cl}$ molal ratio of local meteoric water that generally ranges between 1.0 and 1.1 (Rogora et al., 2006), probably derive from an anthropogenic input. For the few water samples with $\mathrm{Cl}>\mathrm{Na}(\mathrm{Na} / \mathrm{Cl}<1.0)$, the amount of $\mathrm{Cl}$, and consequently all the $\mathrm{X} / \mathrm{Cl}$ ratios, were corrected assuming $\mathrm{Cl}=\mathrm{Na}$.

Second, computation of the dissolved load deriving from silicates dissolution assuming that all $\mathrm{Na}$ and $\mathrm{K}$, after the rain correction, derive from silicate weathering. This assumption is acceptable for the purposes of the study since the rain correction implicitly consider also the possible contribution from halite dissolution, a process which leads to a $\mathrm{Na} / \mathrm{Cl}$ molal ratio in water of 1 , just like rainwater.

The amount of $\mathrm{Ca}$ and $\mathrm{Mg}$ deriving from silicate weathering is computed considering a specific molar ratio, $\mathrm{R}_{\mathrm{sil}}=(\mathrm{Na}+\mathrm{K}) /(\mathrm{Ca}+\mathrm{Mg})$, for

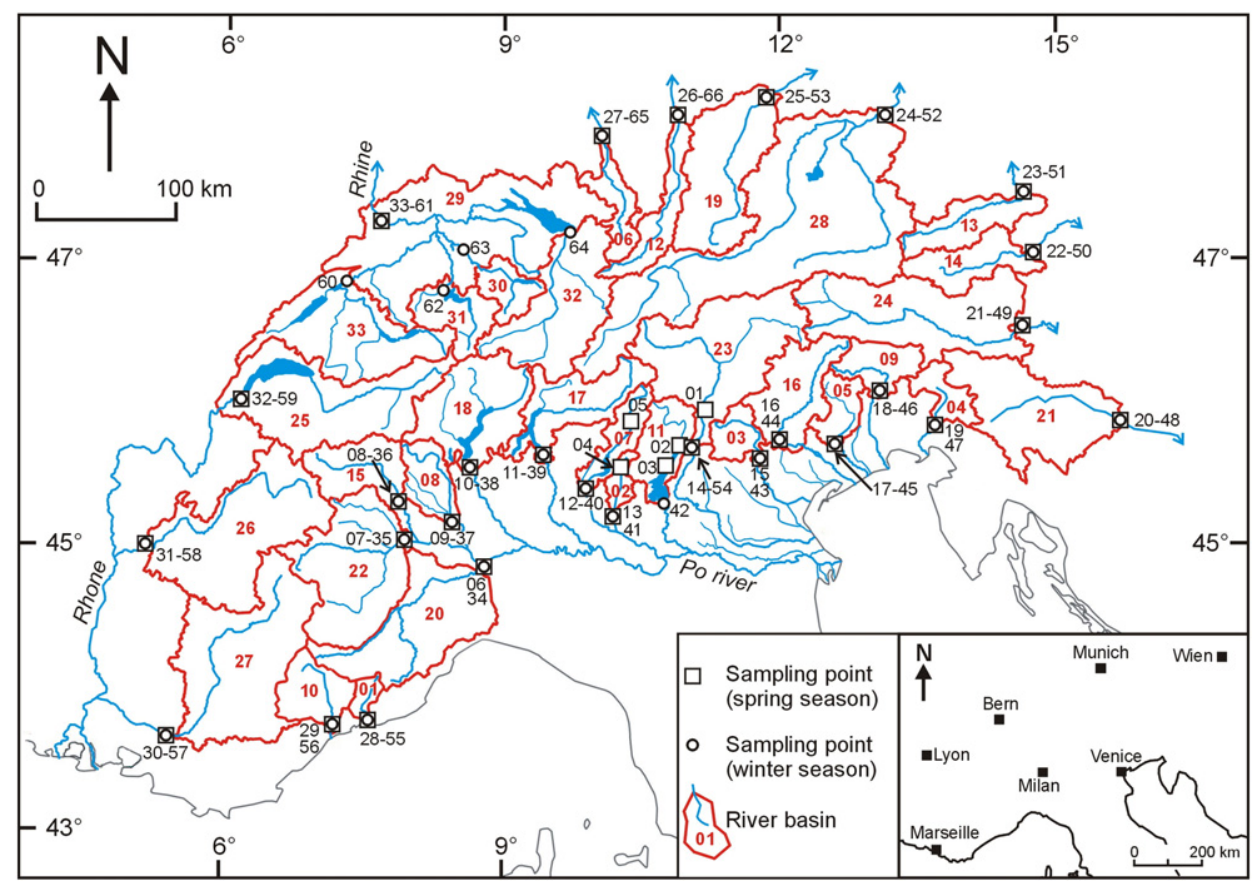

Fig. 2. Selected Alpine drainage basins and location of the sampling points. 
each river basin. The average $(\mathrm{Na}+\mathrm{K}) /(\mathrm{Ca}+\mathrm{Mg})$ molal ratio of each basin ( $\left.R_{\text {sil-mean }}\right)$ was computed as the weighted average of the $R_{\text {sil }}$ values of the various lithologies cropping out in the basin, considering the surface area and the mean precipitation on the surface area of each lithology,

$\mathrm{R}_{\text {sil-mean }}=\frac{\sum_{\mathrm{n}}^{\mathrm{i}=\mathrm{l}}\left(\mathrm{R}_{\text {sil }- \text { litho }-\mathrm{n}} \times \mathrm{S}_{\text {litho }-\mathrm{n}} \times \mathrm{P}_{\text {litho }-\mathrm{n}}\right)}{\sum_{\mathrm{n}}^{\mathrm{i}=\mathrm{l}}\left(\mathrm{S}_{\text {litho }-\mathrm{n}} \times \mathrm{P}_{\text {litho }-\mathrm{n}}\right)}$

where, $\mathrm{R}_{\text {sil-litho-n }}$ is the $(\mathrm{Na}+\mathrm{K}) /(\mathrm{Ca}+\mathrm{Mg})$ ratio of waters interacting with lithology $n, S_{\text {litho-n }}$ is the surface area covered by the lithology $n$ and $P_{\text {litho-n }}$ is the mean value of precipitation over the outcrops of lithology $n$.

For the computation of $\mathrm{R}_{\text {sil-mean }}$ we built a simplified GIS-based geo-lithological map of the Alps (Fig. 3), giving a specific value of $R_{\text {sil }}$ to each lithology according to the literature values estimated from unpolluted French stream waters draining small mono-lithological basins (Meybeck, 1986). Then, we prepared a GIS-based map of the average precipitation on the Alps (Fig. 4a), we established a correlation between terrain elevation and precipitation, and finally we obtained the values of $\mathrm{S}_{\text {litho-n }}$ and $\mathrm{P}_{\text {litho-n }}$ overlapping the geo-lithological map and the digital elevation model.

Third, estimation of the $\mathrm{Ca}$ and $\mathrm{Mg}$ amounts originating from carbonate weathering as the remaining cations after the silicate correction:

$(\mathrm{Ca}+\mathrm{Mg})_{\text {carb }}=(\mathrm{Ca}+\mathrm{Mg})_{\text {river }}-(\mathrm{Ca}+\mathrm{Mg})_{\text {sil }}$.

For samples showing a clear input of Ca due to gypsum or anhydrite dissolution, we applied a further correction subtracting to $(\mathrm{Ca}+\mathrm{Mg})_{\text {carb }}$ the moles of $\mathrm{Ca}$ deriving from sulphate minerals, that is the excess of $\mathrm{SO}_{4}$ with respect to the $\mathrm{SO}_{4} / \mathrm{Cl}$ molal ratio of local meteoric water.

Forth, multiplication of the molal concentrations of the various components of dissolved load by the river flow rate, and division by the catchment area in order to obtain the elemental flux values $\left(F_{X}\right)$ in $\mathrm{mol} \mathrm{km} \mathrm{k}^{-2} \mathrm{y}^{-1}$.
Fifth, computation of the weathering flux, and of the atmospheric/ soil $\mathrm{CO}_{2}$ flux $\left(F_{\mathrm{CO} 2}\right)$ consumed by the rock weathering on short and long-terms using Eqs. (7) and (8).

The procedure was repeated for the spring and the winter seasons.

For the application of the mass balance and for the computation of runoff the following parameters were requested: (i) the daily discharge of each river in the place and at the time of sampling, an information required to transform concentrations to fluxes. These data have been obtained from different sources, including Italian local authorities and Environmental Agencies (ARPA), the Hydrographical Office of Austria, the Federal Office for the Environment in Switzerland, the Environmental Agency of Bavaria, the Meteorological and Hydrological Service of Croatia, and the Ministère de l'Ecologie et du Développement Durable of France. For most catchments, the data were available as flow rates $\left(\mathrm{m}^{3} \mathrm{~s}^{-1}\right)$, but for some catchments only stage measurements at gauging stations were available. These measurements were converted to discharge estimates using specific rating curves; (ii) the area of each catchment, computable from the available DEM data; (iii) the proportions of the lithological types in each catchment, computable from the available geo-lithological maps of Fig. 3, (iv) the mean precipitation for each basin, computable using an empirical relationship linking terrain elevation to precipitation.

Details on the procedures for the estimation of catchment areas, proportions of lithological types and precipitations are given in Sections 3.3, 3.5 and 3.6 respectively.

\subsection{Drainage basins, sampling sites and sampling campaigns}

The main Alpine drainage basins were defined from the highresolution Digital Elevation Model ASTER GDEM (Tachikawa et al., 2011). For each basin, the surface area and the average elevation were computed using GRASS (Neteler and Mitasova, 2008) and QGIS (Quantum GIS Development Team, 2012). After the definition of the drainage basins, we located the sampling stations near the outlet of each basin (Fig. 2, Table 1) and as close as possible to the stations for the measurement of streamflow in order to know the discharge of the river at the time and place of sampling.

The rivers of the study area show average discharge values at the sampling stations ranging from about $100 \mathrm{~m}^{3} / \mathrm{s}$ to more than $1300 \mathrm{~m}^{3} / \mathrm{s}$

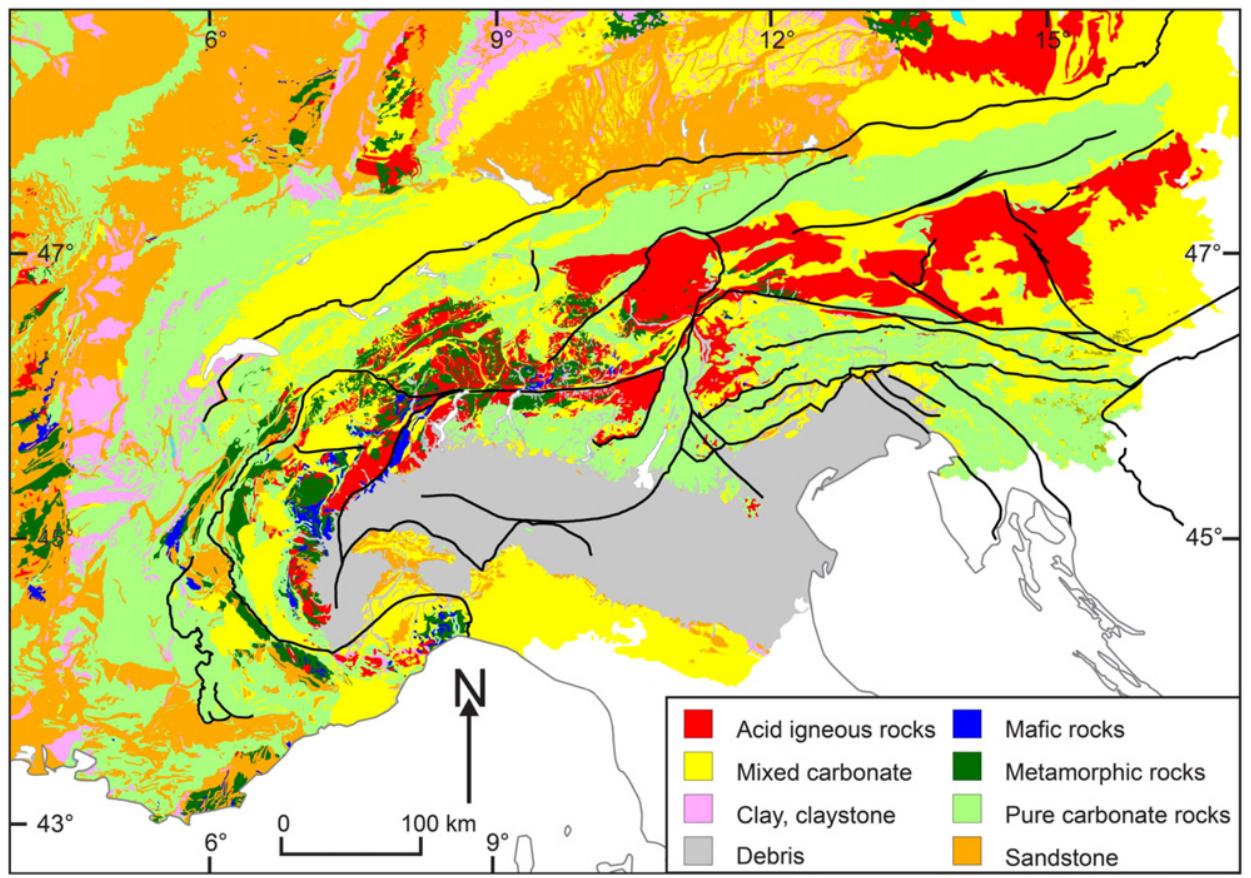

Fig. 3. Geo-lithological map of Alps elaborated according to the lithological classification of Meybeck $(1986,1987)$. 

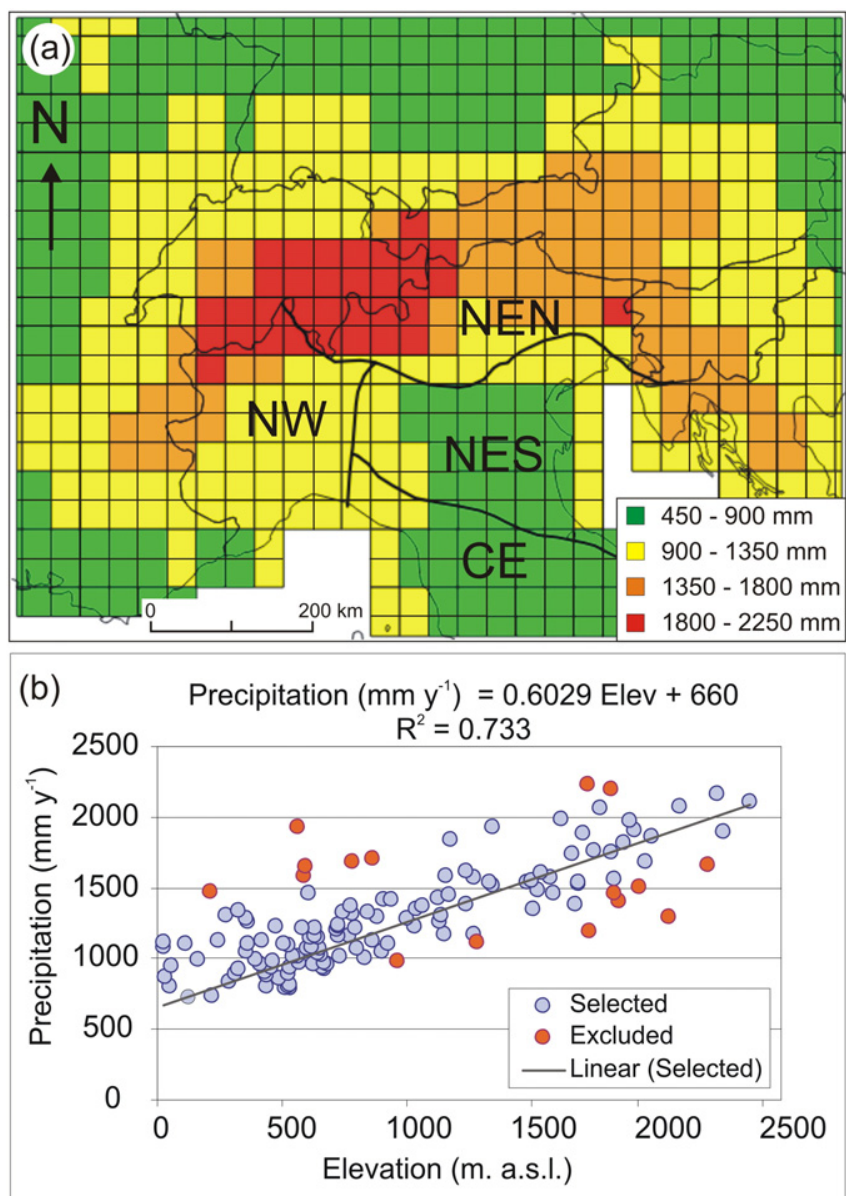

Fig. 4. (a) Mean annual precipitation map for Alpine region elaborated through $R$ software (R Core Team, 2015) starting from the 1961-1990 monthly precipitation (Mitchell and Jones, 2005). The map shows the sub-regions identified by Brunetti et al. (2006): NES (the southern part of north-eastern Italy) with low value of precipitation; CE (central Italy) and NW (north-western Italy) with medium value of precipitation; NEN (northern part of north-eastern Italy) characterized by high values of precipitation. (b) Precipitation vs elevation relationship in Alpine region estimated through the analysis of the distribution of residues method considering the values with residual frequency between $5 \%$ and $95 \%$.

(Rhine at Basel). The highest flows occur during spring and summer and the month with the highest flow ranges between June, for hydrological regimes dominated by snow melting, to April, for snowmelt-rainfall mixed regimes (Bard et al., 2015). In particular the rivers of the northern side of the Alpine Chain are dominated by snow-melting and show a maximum discharge in May-June and a minimum in December-February, while the rivers of Southern Alps, affected by precipitation of Mediterranean origin, are generally characterised by a mixed snowmelt-rainfall regime and show a period of maximum discharge in April-May, a minimum in September, a further maximum in November and a minimum in January-February.

In order to sample the river waters during the periods of maximum and minimum discharge, we planned two sampling campaigns. The first campaign was performed from February 2011 to June 2011 (spring season), and the second campaign was executed from December 2001 to March 2012 (winter season). All the samples of the spring campaign have been collected from April 20th to June 21st; same points originally sampled in February 2011 have been re-sampled in April 2011, except for Mincio river that has been sampled two times in February. The winter campaign was originally planned for the period December 2011February 2012 but some samplings shifted to the first half of March 2012, because the early 2012 European cold wave, characterized intense snowfall and unusually low temperatures.
Table 1

Main features of the studied Alpine basins.

\begin{tabular}{|c|c|c|c|c|c|}
\hline $\begin{array}{l}\text { Basin } \\
\text { ID }\end{array}$ & River name & $\begin{array}{l}\text { Surface } \\
\left(\mathrm{km}^{2}\right)\end{array}$ & $\begin{array}{l}\text { Mean } \\
\text { elevation } \\
(\mathrm{m} \text { asl) }\end{array}$ & $\begin{array}{l}\text { Minimum } \\
\text { elevation } \\
(\mathrm{m} \text { asl) }\end{array}$ & $\begin{array}{l}\text { Maximum } \\
\text { elevation } \\
\text { (m asl) }\end{array}$ \\
\hline 01 & Roia & 663 & 1244 & 7 & 2887 \\
\hline 02 & Mella & 767 & 510 & 44 & 2194 \\
\hline 03 & Brenta & 1601 & 1112 & 53 & 2796 \\
\hline 04 & Isonzo & 1611 & 828 & 12 & 2664 \\
\hline 05 & Livenza & 1770 & 580 & 3 & 2639 \\
\hline 06 & Iller & 2058 & 916 & 484 & 2591 \\
\hline 07 & Oglio & 2099 & 1234 & 87 & 3516 \\
\hline 08 & Sesia & 2298 & 805 & 78 & 4545 \\
\hline 09 & Tagliamento & 2309 & 1049 & 105 & 2728 \\
\hline 10 & Var & 2794 & 1339 & 17 & 3077 \\
\hline 11 & Mincio & 2905 & 1129 & 62 & 3523 \\
\hline 12 & Lech & 2907 & 1154 & 431 & 2956 \\
\hline 13 & Enns & 3179 & 1346 & 446 & 2894 \\
\hline 14 & Mur & 3230 & 1485 & 626 & 3024 \\
\hline 15 & Dora Baltea & 3564 & 2015 & 227 & 4798 \\
\hline 16 & Piave & 4598 & 1265 & 74 & 3273 \\
\hline 17 & Adda & 4707 & 1565 & 121 & 3970 \\
\hline 18 & Ticino & 6614 & 1292 & 111 & 4548 \\
\hline 19 & Isar & 7801 & 771 & 381 & 2940 \\
\hline 20 & Tanaro & 8180 & 644 & 45 & 3204 \\
\hline 21 & Sava & 8337 & 605 & 69 & 2808 \\
\hline 22 & Po & 9058 & 1078 & 100 & 3976 \\
\hline 23 & Adige & 10,197 & 1675 & 41 & 3865 \\
\hline 24 & Drava & 10,492 & 1381 & 363 & 3656 \\
\hline 25 & Rhône & 10,460 & 1549 & 305 & 4777 \\
\hline 26 & Isere & 11,175 & 1514 & 112 & 4023 \\
\hline 27 & Durance & 11,992 & 1281 & 169 & 4037 \\
\hline 28 & Inn & 23,806 & 1326 & 305 & 3991 \\
\hline 29 & Rhine & 36,739 & 1040 & 110 & 4087 \\
\hline 30 & Linth $^{\mathrm{a}}$ & 1814 & 1248 & 185 & 3605 \\
\hline 31 & Reuss $^{\mathrm{a}}$ & 2839 & 1386 & 205 & 3592 \\
\hline 32 & Alpine Rhine ${ }^{\mathrm{a}}$ & 7706 & 1628 & 315 & 3593 \\
\hline 33 & Aare $^{a}$ & 8282 & 1139 & 359 & 4080 \\
\hline 34 & Rhine-Basel $^{\mathrm{a}}$ & 16,098 & 622 & 110 & 2429 \\
\hline
\end{tabular}

a Indicates Rhine sub-basins - basin 29 is the sum of basins 30 to 34 .

In the first sampling campaign we considered 29 river basins with a maximum area of $36,739 \mathrm{~km}^{2}$ (Rhine basin), a minimum area of $663 \mathrm{~km}^{2}$ (Roia basin), and an average catchment area of $6822 \mathrm{~km}^{2}$. We collected 33 samples, one sample for each basin, and two samples for the Mincio, Adige, Mella and Oglio basins. Three of these samples $(01,04$, and 05$)$ were collected upstream of the outlet of the basin (for the Adige, Mella and Oglio basins), whereas for the Mincio basin the two samples were collected at the basin outlet (that coincides with the Garda Lake).

Considering that the Rhine basin is very large when compared to the other Alpine basins and presents a large variability of geologic and climatic conditions, for the second sampling campaign the Rhine basin was further divided into five smaller sub-basins (Linth: $1814 \mathrm{~km}^{2}$; Reuss: $2839 \mathrm{~km}^{2}$; Lower Rhine: $7706 \mathrm{~km}^{2}$; Aare: $8282 \mathrm{~km}^{2}$; RhineBasel: $16,098 \mathrm{~km}^{2}$ ). The sum of the areas of the five Rhine sub-basins exactly coincides with the area of the Rhine basin considered in the first campaign. As a result, we obtained 33 basins with an average area of $5933 \mathrm{~km}^{2}$. During the second campaign we collected 33 samples of river waters, one sample for each drainage basin.

\subsection{Sampling and analytical methods}

For each sample, temperature, electrical conductivity, $\mathrm{pH}$, Eh, silica, total iron, and alkalinity were measured in the field. Silica and total iron were determined using a colorimetric kit, and alkalinity was determined by acid titration with $\mathrm{HCl} 0.1 \mathrm{~N}$ using methyl orange as indicator. Water samples for chemical analyses were filtered with $0.45 \mu \mathrm{m}$ filters, and collected in two polyethylene bottles, the first with a volume of $100 \mathrm{~mL}$ and the second with a volume of $50 \mathrm{~mL}$. The $50 \mathrm{~mL}$ aliquot 
was acidified immediately with $0.5 \mathrm{~mL}$ of concentrated suprapure $\mathrm{HCl}$ in order to stabilize the sample, preventing algal growth and carbonate precipitation. A raw sample for the determination of the isotopic composition of water $\left(\delta \mathrm{D}, \delta^{18} \mathrm{O}\right)$ was collected in the $100 \mathrm{~mL}$ polyethylene bottle, and a further aliquot of $250 \mathrm{~mL}$, acidified with $2.5 \mathrm{~mL}$ of $\mathrm{HNO}_{3}$ and stored in a polyethylene bottle previously treated following the indications of Nisi et al. (2008), was collected for the determination of the ${ }^{86} \mathrm{Sr} /{ }^{87} \mathrm{Sr}$ isotopic ratio.

All the chemical determinations were performed at the Geochemical Laboratory of the Perugia University. Sulphate, $\mathrm{NO}_{3}^{-}, \mathrm{Cl}^{-}$and $\mathrm{F}^{-}$were determined by ion-chromatography. $\mathrm{Ca}^{++}, \mathrm{Mg}^{++}, \mathrm{Sr}^{++}$concentrations were determined by atomic adsorption (AA) flame spectroscopy on the

Table 2

Location, sampling date and field data of river waters sampled in Alpine region.

\begin{tabular}{|c|c|c|c|c|c|c|c|c|}
\hline Sample number & River & Date & Lat & Long & $\mathrm{T}\left({ }^{\circ} \mathrm{C}\right)$ & $\mathrm{pH}$ & Eh (mv) & Cond $(\mu \mathrm{S} / \mathrm{cm})$ \\
\hline 01 & Adige & $9 / 02 / 2011$ & 46.14416 & 11.07477 & 4.20 & 8.19 & 186.00 & 270 \\
\hline 02 & Mincio & $9 / 02 / 2011$ & 45.87467 & 10.8727 & 5.60 & 8.19 & 131.00 & 270 \\
\hline 03 & Mincio & $9 / 02 / 2011$ & 45.72785 & 10.71894 & 8.80 & 8.65 & 147.00 & 240 \\
\hline 04 & Mella & $9 / 02 / 2011$ & 45.72385 & 10.23096 & 7.70 & 8.82 & 92.80 & 350 \\
\hline 05 & Oglio & $9 / 02 / 2011$ & 46.06807 & 10.35133 & 5.60 & 8.51 & 161.00 & 160 \\
\hline 06 & Tanaro & $20 / 04 / 2011$ & 44.9776 & 8.77199 & 15.10 & 8.07 & 237.00 & 475 \\
\hline 07 & Po & $20 / 04 / 2011$ & 45.18217 & 7.88843 & 16.30 & 8.13 & 222.60 & 339 \\
\hline 08 & Dora Baltea & $20 / 04 / 2011$ & 45.46476 & 7.86924 & 11.90 & 8.54 & 197.20 & 255 \\
\hline 09 & Sesia & $21 / 04 / 2011$ & 45.31634 & 8.44058 & 15.60 & 7.78 & 223.80 & 264 \\
\hline 10 & Ticino & $21 / 04 / 2011$ & 45.7233 & 8.6269 & 13.80 & 9.08 & 199.70 & 165 \\
\hline 11 & Adda & $21 / 04 / 2011$ & 45.8224 & 9.41439 & 15.50 & 9.10 & 190.60 & 209 \\
\hline 12 & Oglio & $21 / 04 / 2011$ & 45.56865 & 9.85073 & 15.20 & 8.84 & 213.80 & 300 \\
\hline 13 & Mella & $22 / 04 / 2011$ & 45.35568 & 10.15114 & 14.60 & 7.97 & 209.40 & 757 \\
\hline 14 & Adige & $22 / 04 / 2011$ & 45.86256 & 10.99878 & 12.20 & 8.42 & 207.50 & 257 \\
\hline 15 & Brenta & $22 / 04 / 2011$ & 45.76467 & 11.72935 & 12.40 & 8.80 & 218.10 & 241 \\
\hline 16 & Piave & $22 / 04 / 2011$ & 45.90182 & 11.94685 & 15.30 & 8.65 & 202.60 & 352 \\
\hline 17 & Livenza & $22 / 04 / 2011$ & 45.85054 & 12.53584 & 12.60 & 8.36 & 243.10 & 391 \\
\hline 18 & Tagliamento & $23 / 04 / 2011$ & 46.23386 & 13.04341 & 10.90 & 8.44 & 244.80 & 522 \\
\hline 19 & Isonzo & $23 / 04 / 2011$ & 45.95594 & 13.61318 & 12.90 & 8.51 & 223.70 & 252 \\
\hline 20 & Sava & $4 / 05 / 2011$ & 45.89344 & 15.60565 & 18.10 & 8.85 & 178.50 & 372 \\
\hline 21 & Drava & $4 / 05 / 2011$ & 46.65578 & 14.63523 & 16.30 & 8.51 & 210.20 & 277 \\
\hline 22 & Mur & $5 / 05 / 2011$ & 47.19415 & 14.80768 & 9.50 & 8.53 & 225.30 & 262 \\
\hline 23 & Enns & $5 / 05 / 2011$ & 47.65176 & 14.75044 & 8.50 & 8.27 & 203.30 & 246 \\
\hline 24 & Inn & $5 / 05 / 2011$ & 48.29419 & 13.26731 & 16.40 & 8.77 & 209.50 & 363 \\
\hline 25 & Isar & $6 / 05 / 2011$ & 48.46552 & 11.9461 & 13.00 & 8.47 & 199.10 & 573 \\
\hline 26 & Lech & $6 / 05 / 2011$ & 48.35238 & 10.93827 & 14.00 & 8.47 & 202.20 & 396 \\
\hline 27 & Iller & $6 / 05 / 2011$ & 48.21117 & 10.08225 & 14.30 & 8.36 & 179.60 & 456 \\
\hline 28 & Roia & $20 / 06 / 2011$ & 43.82735 & 7.58289 & 15.40 & 8.39 & 143.00 & 417 \\
\hline 29 & Var & $20 / 06 / 2011$ & 43.78644 & 7.21318 & 18.30 & 8.27 & 156.00 & 425 \\
\hline 30 & Durance & $20 / 06 / 2011$ & 43.66742 & 5.49637 & 21.80 & 8.19 & 135.90 & 520 \\
\hline 31 & Isere & $21 / 06 / 2011$ & 45.08493 & 5.18328 & 16.10 & 8.08 & 134.80 & 355 \\
\hline 32 & Rhone & $21 / 06 / 2011$ & 46.20422 & 6.14981 & 13.00 & 8.21 & 150.10 & 295 \\
\hline 33 & Rhine & $21 / 06 / 2011$ & 47.55529 & 7.60364 & 17.70 & 8.16 & 139.00 & 323 \\
\hline 34 & Tanaro & $5 / 12 / 2011$ & 44.9776 & 8.77199 & 8.00 & 8.07 & 121.10 & 530 \\
\hline 35 & Po & $5 / 12 / 2011$ & 45.18217 & 7.88843 & 10.90 & 7.64 & 144.40 & 340 \\
\hline 36 & Dora Baltea & $5 / 12 / 2011$ & 45.46476 & 7.86924 & 6.60 & 8.21 & 227.80 & 301 \\
\hline 37 & Sesia & $5 / 12 / 2011$ & 45.31634 & 8.44058 & 10.20 & 8.13 & 172.90 & 333 \\
\hline 38 & Ticino & $6 / 12 / 2011$ & 45.7233 & 8.6269 & 9.60 & 7.64 & 234.60 & 157 \\
\hline 39 & Adda & $6 / 12 / 2011$ & 45.8224 & 9.41439 & 11.00 & 7.83 & 191.30 & 184 \\
\hline 40 & Oglio & $6 / 12 / 2011$ & 45.56865 & 9.85073 & 10.40 & 8.23 & 191.00 & 266 \\
\hline 41 & Mella & $6 / 12 / 2011$ & 45.35568 & 10.15114 & 10.80 & 8.00 & 217.00 & 730 \\
\hline 42 & Mincio & $6 / 12 / 2011$ & 45.44484 & 10.69411 & 11.90 & 8.46 & 228.40 & 230 \\
\hline 43 & Brenta & $7 / 12 / 2011$ & 45.76467 & 11.72935 & 6.40 & 8.29 & 239.50 & 272 \\
\hline 44 & Piave & $7 / 12 / 2011$ & 45.90182 & 11.94685 & 8.60 & 8.28 & 188.30 & 365 \\
\hline 45 & Livenza & $7 / 12 / 2011$ & 45.85054 & 12.53584 & 8.30 & 8.19 & 207.30 & 370 \\
\hline 46 & Tagliamento & $7 / 12 / 2011$ & 46.23552 & 13.04348 & 12.60 & 7.82 & 242.40 & 472 \\
\hline 47 & Isonzo & $8 / 12 / 2011$ & 45.95594 & 13.61318 & 7.20 & 8.24 & 189.00 & 268 \\
\hline 48 & Sava & $8 / 12 / 2011$ & 45.89344 & 15.60565 & 11.20 & 8.29 & 115.50 & 388 \\
\hline 49 & Drava & $8 / 12 / 2011$ & 46.65578 & 14.63523 & 3.40 & 8.15 & 169.80 & 322 \\
\hline 50 & Mur & $9 / 12 / 2011$ & 47.19415 & 14.80768 & 2.10 & 8.14 & 277.80 & 308 \\
\hline 51 & Enns & $9 / 12 / 2011$ & 47.65176 & 14.75044 & 3.00 & 8.23 & 215.20 & 332 \\
\hline 52 & Inn & $9 / 12 / 2011$ & 48.29419 & 13.26731 & 5.40 & 8.16 & 216.50 & 391 \\
\hline 53 & Isar & $9 / 12 / 2011$ & 48.46552 & 11.9461 & 8.40 & 8.30 & 197.80 & 579 \\
\hline 54 & Adige & $10 / 12 / 2011$ & 45.86256 & 10.99878 & 5.00 & 8.29 & 137.70 & 301 \\
\hline 55 & Roia & $12 / 03 / 2012$ & 43.8153 & 7.59058 & 10.70 & 8.44 & 142.30 & 621 \\
\hline 56 & Var & $12 / 03 / 2012$ & 43.7721 & 7.21285 & 10.10 & 8.31 & 137.80 & 643 \\
\hline 57 & Durance & $12 / 03 / 2012$ & 43.6663 & 5.49444 & 11.10 & 8.44 & 186.40 & 526 \\
\hline 58 & Isere & 13/03/2012 & 45.08493 & 5.18328 & 8.10 & 8.15 & 157.00 & 577 \\
\hline 59 & Rhone & 13/03/2012 & 46.20977 & 6.16694 & 7.80 & 8.31 & 139.70 & 304 \\
\hline 60 & Aare & $14 / 03 / 2012$ & 47.12334 & 7.23137 & 5.10 & 8.18 & 183.50 & 379 \\
\hline 61 & Rhine & $14 / 03 / 2012$ & 47.55678 & 7.60082 & 8.60 & 8.48 & 140.60 & 387 \\
\hline 62 & Reuss & $14 / 03 / 2012$ & 47.04597 & 8.32246 & 8.80 & 8.56 & 185.90 & 225 \\
\hline 63 & Linth & 15/03/2012 & 47.35893 & 8.53721 & 6.10 & 8.30 & 214.30 & 296 \\
\hline 64 & Alpine Rhine & 15/03/2012 & 47.49888 & 9.70219 & 5.10 & 8.45 & 208.80 & 315 \\
\hline 65 & Iller & $15 / 03 / 2012$ & 48.2112 & 10.08225 & 7.60 & 8.19 & 192.00 & 509 \\
\hline 66 & Lech & $15 / 03 / 2012$ & 48.35235 & 10.93812 & 8.00 & 8.39 & nd & 436 \\
\hline
\end{tabular}


acidified sample, whereas $\mathrm{Na}^{+}, \mathrm{K}^{+}, \mathrm{Li}^{+}$and $\mathrm{Rb}^{+}$were determined by atomic emission (AE) flame spectroscopy. The detection limits are: $0.01 \mathrm{mg} / \mathrm{L}$ for $\mathrm{Ca}^{++}, \mathrm{Mg}^{++}, \mathrm{Na}^{+}, \mathrm{K}^{+}, \mathrm{F}^{-}, \mathrm{NO}^{-}, \mathrm{Sr}^{++} ; 0.03 \mathrm{mg} / \mathrm{L}$ for $\mathrm{Cl}^{-}$and $\mathrm{SO}^{-}$; and $0.01 \mu \mathrm{g} / \mathrm{l}$ for $\mathrm{Li}^{+}$and $\mathrm{Rb}^{+}$. All the laboratory analytical methods and the field alkalinity determinations have an accuracy better than $2 \%$. The total analytical error, evaluated checking the charge balance, is about $2.5 \%$ on average, and is lower than $2 \%$ for $44 \%$ of the samples.

Table 3

Chemical and isotopic composition of river waters sampled in Alpine region.

\begin{tabular}{|c|c|c|c|c|c|c|c|c|c|c|c|c|c|c|c|}
\hline \multirow[t]{2}{*}{ ID } & \multirow{2}{*}{$\frac{\mathrm{Ca}}{(\mathrm{mg} / \mathrm{L})}$} & \multirow{2}{*}{$\frac{\mathrm{Mg}}{(\mathrm{mg} / \mathrm{L})}$} & \multirow{2}{*}{$\frac{\mathrm{Na}}{(\mathrm{mg} / \mathrm{L})}$} & \multirow{2}{*}{$\frac{\mathrm{K}}{(\mathrm{mg} / \mathrm{L})}$} & \multirow{2}{*}{$\frac{\mathrm{Sr}}{(\mathrm{mg} / \mathrm{L})}$} & \multirow{2}{*}{$\frac{\mathrm{Li}}{(\mu \mathrm{g} / \mathrm{L})}$} & $\mathrm{Rb}$ & $\mathrm{HCO}_{3}$ & $\mathrm{SO}_{4}$ & $\mathrm{Cl}$ & $\mathrm{NO}_{3}$ & $\mathrm{~F}$ & $\delta^{18} \mathrm{O}$ & $\delta \mathrm{D}$ & ${ }^{87} \mathrm{Sr} /{ }^{86} \mathrm{Sr}$ \\
\hline & & & & & & & $(\mu \mathrm{g} / \mathrm{L})$ & $(\mathrm{mg} / \mathrm{L})$ & $(\mathrm{mg} / \mathrm{L})$ & $(\mathrm{mg} / \mathrm{L})$ & $(\mathrm{mg} / \mathrm{L})$ & $(\mathrm{mg} / \mathrm{L})$ & (\%。 vs V-SMOW) & (\%。 vs V-SMOW) & \\
\hline 01 & 32.40 & 10.06 & 4.12 & 3.17 & 0.17 & 4.14 & 2.4 & 125.86 & 17.06 & 5.41 & 5.60 & 0.06 & -11.92 & -85.1 & 0.710980 \\
\hline 02 & 38.00 & 9.14 & 5.23 & 2.06 & 0.14 & 1.95 & 2.1 & 144.52 & 7.17 & 6.62 & 8.37 & 0.04 & -11.00 & -75.1 & 0.709697 \\
\hline 03 & 30.80 & 7.50 & 4.42 & 1.21 & 0.14 & 3.05 & $<1.7$ & 122.29 & 10.59 & 5.63 & 0.89 & 0.06 & -7.63 & -55.1 & 0.708583 \\
\hline 04 & 46.70 & 10.39 & 3.52 & 1.89 & 0.66 & 5.81 & $<1.7$ & 159.62 & 36.35 & 4.94 & 3.44 & 0.08 & -9.39 & -61.6 & 0.708366 \\
\hline 05 & 16.00 & 4.47 & 4.62 & 2.99 & 0.10 & 1.88 & $<1.7$ & 59.70 & 14.83 & 3.31 & 4.32 & 0.06 & -11.05 & -72.5 & 0.720819 \\
\hline 06 & 59.90 & 10.48 & 13.97 & 1.85 & 0.48 & 5.18 & 2.6 & 172.94 & 53.15 & 20.46 & 11.23 & 0.11 & -11.47 & -78.7 & 0.709166 \\
\hline 07 & 38.00 & 8.91 & 10.83 & 4.75 & 0.35 & 2.26 & 2.5 & 115.70 & 37.17 & 14.94 & 12.83 & 0.06 & -11.51 & -80.2 & 0.709421 \\
\hline 08 & 34.10 & 4.84 & 4.40 & 2.36 & 0.37 & 3.80 & 2.5 & 89.62 & 38.45 & 6.23 & 2.37 & 0.06 & -13.7 & -98.1 & 0.709383 \\
\hline 09 & 26.40 & 6.07 & 9.95 & 3.00 & 0.20 & 1.17 & 2.7 & 85.78 & 27.49 & 13.37 & 7.67 & 0.10 & -10.36 & -72.0 & 0.709836 \\
\hline 10 & 19.95 & 3.13 & 3.47 & 1.63 & 0.21 & 1.11 & 3.6 & 51.61 & 26.80 & 3.56 & 3.48 & 0.07 & -10.30 & -66.9 & 0.708819 \\
\hline 11 & 25.10 & 5.67 & 3.58 & 2.68 & 0.21 & 1.84 & 3.0 & 83.59 & 24.33 & 4.27 & 3.14 & 0.08 & -10.32 & -68.9 & 0.710039 \\
\hline 12 & 40.35 & 6.87 & 4.25 & 1.40 & 0.51 & 1.95 & $<1.7$ & 118.77 & 42.10 & 4.76 & 3.55 & 0.08 & -9.71 & -67.2 & 0.708671 \\
\hline 13 & 96.50 & 10.53 & 22.43 & 4.34 & 0.52 & 3.43 & 2.6 & 301.95 & 53.03 & 35.08 & 27.45 & 0.14 & -8.31 & -56.5 & 0.708557 \\
\hline 14 & 31.28 & 7.14 & 5.20 & 2.28 & 0.21 & 4.14 & 3.0 & 107.33 & 29.85 & 6.33 & 2.87 & 0.09 & -12.03 & -86.0 & 0.710404 \\
\hline 15 & 33.13 & 6.69 & 2.39 & 0.69 & 0.07 & 1.23 & $<1.7$ & 124.07 & 13.77 & 2.72 & 3.49 & 0.06 & -10.85 & -70.6 & 0.709200 \\
\hline 16 & 47.95 & 10.27 & 3.14 & 0.83 & 0.29 & 2.07 & 1.9 & 170.33 & 33.66 & 3.19 & 3.78 & 0.07 & -9.96 & -64.0 & 0.707802 \\
\hline 17 & 55.00 & 10.17 & 3.01 & 1.27 & 0.34 & 2.14 & 2.1 & 188.03 & 35.18 & 3.44 & 6.06 & 0.07 & -9.78 & -65.9 & 0.707987 \\
\hline 18 & 77.90 & 10.12 & 2.65 & 0.56 & 1.25 & 3.01 & 2.3 & 109.25 & 141.06 & 2.57 & 2.77 & 0.14 & -9.55 & -64.4 & 0.707736 \\
\hline 19 & 35.85 & 7.39 & 10.76 & 0.36 & 0.05 & 7.78 & $<1.7$ & 160.74 & 5.40 & 1.68 & 2.30 & 0.03 & -9.11 & -57.4 & 0.708168 \\
\hline 20 & 49.73 & 12.72 & 6.43 & 0.75 & 0.11 & 1.64 & 2.2 & 196.13 & 13.98 & 7.82 & 4.41 & 0.09 & -9.39 & -63.6 & 0.708653 \\
\hline 21 & 34.05 & 8.04 & 5.00 & 0.85 & 0.23 & 2.67 & 2.3 & 122.98 & 23.19 & 5.48 & 2.67 & 0.12 & -11.54 & -80.5 & 0.709909 \\
\hline 22 & 24.90 & 4.74 & 17.52 & 2.46 & 0.10 & 2.22 & 9.7 & 94.15 & 34.60 & 3.95 & 1.28 & 0.07 & -12.34 & -86.8 & 0.710915 \\
\hline 23 & 31.13 & 7.00 & 2.81 & 0.41 & 0.15 & 1.31 & $<1.7$ & 112.00 & 19.96 & 3.61 & 2.50 & 0.08 & -12.58 & -88.3 & 0.709659 \\
\hline 24 & 46.60 & 10.59 & 7.65 & 1.18 & 0.22 & 3.09 & 2.6 & 169.81 & 21.62 & 11.78 & 5.41 & 0.12 & -12.17 & -87.3 & 0.709247 \\
\hline 25 & 72.20 & 19.80 & 15.60 & 2.02 & 0.26 & 2.26 & 3.5 & 273.13 & 19.44 & 24.73 & 11.78 & 0.11 & -9.15 & -68.6 & 0.708766 \\
\hline 26 & 50.35 & 15.08 & 5.50 & 1.49 & 0.40 & 2.64 & $<1.7$ & 199.29 & 23.34 & 7.42 & 4.62 & 0.12 & -11.96 & -87.8 & 0.707868 \\
\hline 27 & 61.40 & 10.96 & 9.39 & 3.28 & 0.45 & 2.26 & 3.0 & 192.97 & 15.83 & 19.85 & 8.31 & 0.09 & -11.33 & -81.0 & 0.707930 \\
\hline 28 & 63.00 & 9.06 & 1.95 & 0.11 & 1.20 & 4.44 & 2.5 & 101.15 & 120.56 & 1.66 & 0.30 & 0.10 & -10.72 & -72.5 & 0.708181 \\
\hline 29 & 59.00 & 7.26 & 7.94 & 0.41 & 1.06 & 8.44 & 2.2 & 86.47 & 112.70 & 13.34 & 0.64 & 0.16 & -11.10 & -74.6 & 0.708284 \\
\hline 30 & 68.80 & 10.65 & 10.20 & 0.63 & 1.19 & 8.76 & $<1.7$ & 137.25 & 95.30 & 19.53 & 3.72 & 0.12 & -10.63 & -74.2 & 0.708143 \\
\hline 31 & 51.20 & 5.67 & 4.89 & 0.54 & 0.73 & 4.25 & 2.6 & 109.80 & 74.65 & 9.15 & 2.80 & 0.10 & -12.41 & -87.7 & 0.708874 \\
\hline 32 & 40.90 & 4.96 & 5.42 & 1.31 & 0.52 & 6.77 & 3.8 & 95.53 & 48.58 & 10.68 & 2.54 & 0.13 & -12.23 & -91.0 & nd \\
\hline 33 & 48.35 & 5.71 & 5.92 & 0.94 & 0.40 & 8.26 & 2.8 & 148.23 & 29.32 & 10.74 & 5.29 & 0.10 & -11.02 & -81 & 0.708575 \\
\hline 34 & 66.10 & 10.04 & 18.35 & 2.45 & 0.53 & nd & nd & 201.76 & 53.37 & 22.59 & 11.54 & 0.08 & -10.62 & -76.4 & 0.709167 \\
\hline 35 & 33.65 & 8.76 & 14.62 & 3.02 & 0.27 & nd & nd & 114.74 & 30.29 & 16.58 & 10.74 & 0.04 & -10.68 & -74.5 & 0.709776 \\
\hline 36 & 39.55 & 6.93 & 4.73 & 1.52 & 0.44 & nd & nd & 103.21 & 45.10 & 5.25 & 2.86 & 0.05 & -12.80 & -93.7 & 0.709345 \\
\hline 37 & 34.75 & 8.20 & 10.20 & 2.54 & 0.35 & nd & nd & 113.09 & 33.66 & 12.02 & 8.77 & 0.05 & -10.77 & -74.7 & 0.709504 \\
\hline 38 & 17.90 & 3.06 & 3.02 & 1.39 & 0.22 & nd & nd & 41.18 & 24.32 & 2.78 & 2.86 & 0.05 & -9.66 & -67.3 & 0.708834 \\
\hline 39 & 21.10 & 5.11 & 3.12 & 1.23 & 0.18 & nd & nd & 77.41 & 20.25 & 2.68 & 2.95 & 0.05 & -10.28 & -71.8 & 0.710743 \\
\hline 40 & 34.25 & 6.67 & 3.51 & 1.36 & 0.48 & nd & nd & 101.02 & 31.81 & 3.58 & 3.40 & 0.05 & -9.72 & -68.7 & 0.708803 \\
\hline 41 & 88.60 & 9.37 & 24.60 & 3.76 & 0.60 & nd & nd & 292.07 & 44.49 & 33.00 & 26.41 & 0.09 & -8.45 & -58.5 & 0.708543 \\
\hline 42 & 28.65 & 7.85 & 4.15 & 1.14 & 0.14 & nd & nd & 116.39 & 9.77 & 5.48 & 1.38 & 0.04 & -7.37 & -55.9 & 0.708626 \\
\hline 43 & 36.20 & 7.98 & 2.18 & 0.72 & 0.11 & nd & nd & 163.05 & 14.98 & 2.40 & 3.96 & 0.06 & -9.76 & -68.9 & 0.708959 \\
\hline 44 & 46.20 & 9.29 & 3.40 & 1.25 & 0.18 & nd & nd & 204.78 & 14.99 & 3.51 & 5.63 & 0.04 & -8.83 & -60.7 & 0.707842 \\
\hline 45 & 50.70 & 9.29 & 2.60 & 0.85 & 0.35 & nd & nd & 175.68 & 31.21 & 2.53 & 5.53 & 0.06 & -9.42 & -65.2 & 0.707988 \\
\hline 46 & 61.65 & 9.28 & 2.82 & 0.72 & 1.04 & nd & nd & 152.35 & 92.01 & 2.44 & 3.04 & 0.12 & -8.89 & -60.1 & 0.707835 \\
\hline 47 & 37.70 & 7.63 & 1.41 & 0.47 & 0.07 & nd & nd & 170.74 & 4.76 & 1.78 & 4.03 & 0.04 & -8.16 & -53.3 & 0.708192 \\
\hline 48 & 49.05 & 9.31 & 6.63 & 1.35 & 0.16 & nd & nd & 205.88 & 15.69 & 8.16 & 6.74 & 0.05 & -9.00 & -60.0 & 0.708598 \\
\hline 49 & 36.85 & 9.32 & 6.91 & 1.54 & 0.28 & nd & nd & 138.90 & 27.04 & 6.56 & 3.77 & 0.08 & -10.82 & -74.0 & 0.709888 \\
\hline 50 & 32.45 & 7.00 & 12.68 & 2.32 & 0.16 & nd & nd & 150.98 & 29.88 & 8.87 & 2.86 & 0.06 & -11.55 & -80.5 & 0.711100 \\
\hline 51 & 37.55 & 9.40 & 6.31 & 1.16 & 0.27 & nd & nd & 145.49 & 30.02 & 9.47 & 3.29 & 0.04 & -12.00 & -86.7 & 0.710065 \\
\hline 52 & 46.45 & 9.44 & 8.24 & 2.00 & 0.29 & nd & nd & 172.39 & 24.10 & 12.51 & 6.75 & 0.07 & -11.52 & -80.6 & 0.709194 \\
\hline 53 & 68.80 & 9.47 & 15.34 & 3.30 & 0.25 & nd & nd & 282.19 & 20.34 & 25.25 & 14.09 & 0.07 & -9.23 & -70.0 & 0.708881 \\
\hline 54 & 33.80 & 8.85 & 5.87 & 2.05 & 0.27 & nd & nd & 114.19 & 36.96 & 6.64 & 3.51 & 0.12 & -11.73 & -82.2 & 0.710585 \\
\hline 55 & 101.47 & 15.31 & 8.73 & 0.78 & 2.17 & nd & nd & 156.00 & 186.19 & 8.00 & 1.30 & 0.11 & -9.85 & -66.0 & 0.708108 \\
\hline 56 & 97.85 & 11.06 & 19.81 & 1.10 & 1.76 & nd & nd & 154.80 & 160.43 & 22.53 & 1.61 & 0.20 & -9.71 & -67.7 & 0.708189 \\
\hline 57 & 70.80 & 9.05 & 18.16 & 0.96 & 0.93 & nd & nd & 200.70 & 56.35 & 23.16 & 4.79 & 0.10 & -9.23 & -66.3 & 0.708042 \\
\hline 58 & 81.50 & 8.91 & 13.79 & 0.95 & 1.34 & nd & nd & 162.90 & 106.18 & 17.17 & 5.34 & 0.10 & -11.66 & -84.5 & 0.708677 \\
\hline 59 & 42.30 & 4.53 & 6.91 & 2.21 & 0.54 & nd & nd & 110.70 & 40.12 & 9.42 & 2.34 & 0.11 & -12.15 & -89.1 & 0.708741 \\
\hline 60 & 57.50 & 4.95 & 6.86 & 1.28 & 0.45 & nd & nd & 164.70 & 23.86 & 9.10 & 6.59 & 0.08 & -10.21 & -73.3 & 0.708102 \\
\hline 61 & 52.40 & 6.05 & 10.25 & 1.31 & 0.44 & nd & nd & 169.20 & 24.60 & 12.29 & 6.52 & 0.11 & -10.67 & -77.5 & 0.708437 \\
\hline 62 & 36.90 & 2.57 & 2.58 & 0.74 & 0.29 & nd & nd & 110.70 & 12.68 & 2.39 & 3.15 & 0.08 & -11.66 & -87.3 & 0.708249 \\
\hline 63 & 44.40 & 4.53 & 5.25 & 1.66 & 0.35 & nd & nd & 148.50 & 12.84 & 5.76 & 2.82 & 0.11 & -10.95 & -74.9 & 0.709032 \\
\hline 64 & 51.10 & 4.46 & 3.41 & 0.56 & 0.34 & nd & nd & 182.70 & 7.22 & 4.02 & 3.51 & 0.07 & -11.6 & -82.2 & 0.707872 \\
\hline 65 & 70.10 & 10.56 & 12.33 & 1.36 & 0.43 & nd & nd & 247.50 & 11.72 & 22.73 & 10.11 & 0.08 & -10.79 & -80.8 & 0.708002 \\
\hline 66 & 57.75 & 13.64 & 7.24 & 0.86 & 0.45 & nd & nd & 219.60 & 22.76 & 8.57 & 6.06 & 0.11 & -11.39 & -79.6 & 0.707873 \\
\hline
\end{tabular}

nd $=$ not detected. 
The Sr isotopic analyses were performed by Thermal Ionization Mass Spectrometry (TIMS) at the laboratory of Midi-Pyrénées Observatory (OMP, Toulouse), and the isotopic analysis of ${ }^{18} \mathrm{O}$ and $\mathrm{D}$ of water were performed by means of standard mass spectrometry techniques at INGV-OV (Napoli) and CNR-IGG (Pisa). The values of $\delta \mathrm{D}\left({ }^{2} \mathrm{H} /{ }^{1} \mathrm{H}\right)$ and of $\delta^{18} \mathrm{O}\left({ }^{18} \mathrm{O} /{ }^{16} \mathrm{O}\right)$ are referred as $\delta(\%)$ of the standard V-SMOW (Vienna Standard Mean Ocean Water). Analytical errors are: $\pm 1 \%$ for $\delta D$, $\pm 0.08 \%$ or for $\delta^{18} \mathrm{O}$, and less than $1 \%$ for the ${ }^{87} \mathrm{Sr} /{ }^{86} \mathrm{Sr}$ ratio. The physical parameters and the results of the chemical and isotopic analysis of river waters are summarized in Tables 2 and 3.

\subsection{GIS-based geo-lithological map of Alps}

Exploiting published maps in digital formats, we assembled a GIS-based, high resolution $(1: 1,000,000)$, geo-lithological map using GRASS (Neteler and Mitasova, 2008) and QGIS (Quantum GIS Development Team, 2012). The data were taken from (i) the Geological Map of Italy at 1:1,000,000 scale (http://www.isprambiente.gov.it), (ii) the Geological Map of Switzerland at 1:500,000 scale (http://www swisstopo.admin.ch), (iii) the Geological Map of France at 1:1,000,000 scale, (iv) the Geological Map of Slovenia at 1:250,000 scale, obtained from the European Geological Metadata Catalogue (http://one.geology. $\mathrm{cz} /$ ), (v) the Geological Map of Germany at 1:1,000,000 scale (BGR, 2011), (vi) the Geological Map of Austria at 1:2,000,000 scale (Egger et al., 1999), (vi) the Tectonic Map of the Alps (Schmid et al., 2004) at 1:500,000 scale, and (vii) the Geological Map of the Alps (Garzanti et al., 2010).

As highlighted by Amiotte-Suchet et al. (2003), one of the most important points for the study of the fluxes of matter from rock and soils to rivers and oceans is the presence of carbonate minerals. For this reason, in our map we first divided the carbonate rocks from the silicate rocks. The carbonate rocks were further subdivided in: (1) pure carbonate rocks (dolostone, limestone) and (2) mixed carbonate rocks (marls and other rocks with $<50 \%$ of carbonate). Silicate rocks, according to Meybeck (1987), were subdivided in: (3) acid igneous rocks, (4) mafic rocks, (5) clay and claystones, and (6) sand and sandstones. The remaining formations were subdivided in (7) generic metamorphic rocks, (8) debris, (9) mud, and (10) peat. The subdivision between "acid rocks" and "mafic rocks" was done according to the QAPF (IUGS, 1973) and TAS (Le Bas et al., 1986) diagrams.

Since for the application of Eq. (9) it is necessary to know the chemical composition of the outcropping rocks, we classified metamorphic rocks according to the chemistry of protolytes (for example, a metaquartzite was considered a sandstone, and a marble a pure carbonate rock). Where data on protolytes were unavailable or unclear, we attributed the metamorphic lithologies to the generic class (7).

The results (Table 4) show that the most abundant rock types are "carbonate rocks", covering $48.13 \%$ of the study area (27.69\% of pure carbonate rocks, and $20.44 \%$ of mixed carbonate rocks) followed by "sand and sandstones" (20.34\%), and acid igneous rocks (14.25\%).

Table 4

Relative abundance of outcropping rocks in the drainage area of the 32 river basins considered in this work, according to the geo-lithological map of the Alps of Fig. 3.

\begin{tabular}{lc}
\hline Rock type & \% Area \\
\hline Pure carbonate rocks & 27.69 \\
Mixed carbonate rocks & 20.44 \\
Sand, sandstones & 20.34 \\
Acid igneous rocks & 14.25 \\
Metamorphic rocks & 6.76 \\
Debris & 6.48 \\
Clay, claystones & 1.54 \\
Mafic rocks & 1.22 \\
Other rock types & 1.27
\end{tabular}

In the geo-lithological map (Fig. 3) the areas characterized by carbonate rocks encompass the Jura Mountains located in the northwestern Alps, predominantly between France and Switzerland, the Northern Calcareous Alps located north of the Periadriatic Line in Austria and south-eastern Germany and the south-eastern Calcareous Alps located in Italy, Slovenia and partly in Austria.

Mixed carbonate rocks are mainly present in the Molasse Basin, a Cenozoic foredeep basin that extends from France to the eastern border of Austria, with repeated alternations of shallow marine and freshwater deposits (Dal Piaz et al., 2003).

Silicate rocks crop out mainly in the inner core of the Alps where the main crystalline complexes are located, including the Argentera Massif, the Mont Blanc, the Gran Paradiso, the Sesia zone, the Lepontine Alps, the Saint Gotthard, the Oztal complex, and the Australpine Crystalline complexes.

It is interesting to compare the distribution of the rock types in the study area with the world average lithologies. Recently, a new highresolution global lithological map (GLiM) was assembled from existing regional geological maps (Hartmann and Moosdorf, 2012). According to the GLiM, the continents are covered by $64 \%$ sediments (a third of which are carbonates), $13 \%$ metamorphics, $7 \%$ plutonics, $6 \%$ volcanics, and $10 \%$ is water or ice. If we exclude from the computation the $10 \%$ of the continents that are covered by water and ice, it results that about $71 \%$ of the outcropping rocks belong to sedimentary formations (24\% carbonates and $47 \%$ sand and sandstones, clay or mixed sedimentary formations) and about $29 \%$ are igneous or metamorphic rocks. This data basically confirm the previous estimations of Amiotte-Suchet et al. (2003) and indicate that the lithology of the Alpine area roughly approximates the world lithological distribution with a slight overestimation of sedimentary rocks, and a small underestimation of igneous and metamorphic rocks (Table 4).

\subsection{Distribution of precipitations in the Alpine region}

To use Eq. (9), information on the precipitation for each rock type in each basin is required. We obtained this information by interpolating 1961-1990 average monthly precipitation measurements (Mitchell and Jones, 2005).

Visual inspection of the mean annual precipitation map for the Alps (Fig. 4a) reveals an arc-shaped zone corresponding to the Alpine chain, characterized by high values of precipitation, with the highest precipitation values in the eastern sector of Italian Alps (Friuli-Venezia Giulia) and in central Alps. The obtained mean annual precipitation map was overlapped to the ASTER GDEM (Tachikawa et al., 2011) and then for each cell of the mean annual precipitation map we estimated the mean elevation form the digital elevation model. The linear correlation between precipitation $\left(\mathrm{mm} \mathrm{y}^{-1}\right)$ and terrain elevation $(\mathrm{m})$ was estimated using a robust fitting approach. 17 of 176 points were excluded and considered outlier, because their residual from a linear fitting model were outside the 5th and 95th percentile range. From the linear fitting of the final subset of 159 values we obtained the following equation:

Precipitation $=0.6029\left(\mathrm{~mm} \mathrm{y}^{-1}\right) \times$ Elevation $(\mathrm{m})+660$

with a coefficient of determination $\mathrm{R}^{2}=0.733$ (Fig. $4 \mathrm{~b}$ ).

Table 5 shows for the linear coefficients the estimated values, the associated standard error (Std. Error), the t value and the p values (R Core

Table 5

Results of the linear regression ( $\mathrm{R}$ Core Team, 2015) of precipitation $\left(\mathrm{mm} \mathrm{y}^{-1}\right)$ and terrain elevation $(\mathrm{m})$ data the in Alpine region.

\begin{tabular}{lccll}
\hline & Estimated value & Std. error & T value & P value \\
\hline Intercept & 660 & 27.88 & 23.68 & $2 \times 10^{16}$ \\
Angular coefficient & 0.6029 & 0.029 & 20.76 & $2 \times 10^{-16}$
\end{tabular}


Team, 2015). As shown by the p values in the table, both the coefficient estimated are significant.

\section{Results}

\subsection{Chemical and isotopic composition of river waters}

In the diagram $\delta^{18} \mathrm{O}$ vs $\delta \mathrm{D}$, the samples of the Alpine rivers (Fig. 5) are close to the global meteoric water line (Craig, 1961), show a marked altitude effect and don't show any evident isotopic shift due to evaporation (in the studied rivers runoff prevail over evaporation). Furthermore there is no evident mixing trend with deep thermal water (in the Alps many thermal springs are present but their contribution to total river discharge is negligible).All the samples are below the meteoric water line of the Mediterranean area (IAEA, 1981; Longinelli and Selmo, 2003), indicating that the largest part of precipitations in the Alps derive from weather fronts originating in the Atlantic ocean or in the Eurasian continent.

The investigated waters were in the range $2.1{ }^{\circ} \mathrm{C}-21.8^{\circ} \mathrm{C}$, had $\mathrm{pH}$ values from 7.64 to 9.10 , and exhibited positive Eh values (>100 mV). Total dissolved solids (TDS) varied between 96 and $551 \mathrm{mg} / \mathrm{L}$ and, on average, were slightly higher for samples taken in the winter campaign (mean of spring campaign TDS $=253 \pm 89 \mathrm{mg} / \mathrm{L}$; mean of winter campaign TDS $=283 \pm 101 \mathrm{mg} / \mathrm{L}$ ). This variation is probably related to the dilution effect related to snow melting during the spring and the relative higher contribution of groundwater during winter.

The Langelier-Ludwig diagram (Fig. 6) shows that most of the waters are characterized by a bicarbonate earth-alkaline composition. Some samples show a clear trend towards a sulphate composition, and other samples a slight enrichment in alkaline metals. The prevalent bicarbonate earth-alkaline composition is due to the dissolution of carbonates that are present in all the considered catchments. The sulphate enrichment that characterizes the rivers from SE France, Roia, Var, Isere and Durance (Olivier et al., 2009) and the Tagliamento River in the SE Italian Alps (Stefanini, 1976), is likely to depend primarily on the interaction with gypsum layers that are present within the Triassic carbonate sequences present in the areas. The slight increase in alkaline metals

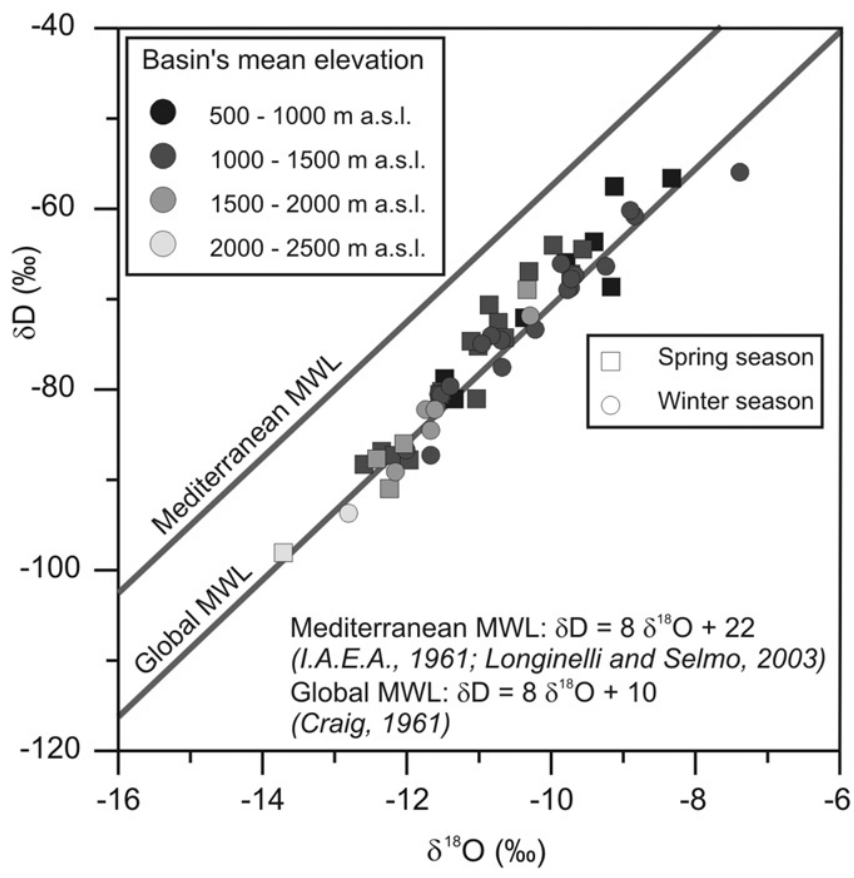

Fig. 5. $\delta \mathrm{D} V s \delta^{18} \mathrm{O}$ for the sampled river waters. The mean elevation of each basins and the sampling season are highlighted.

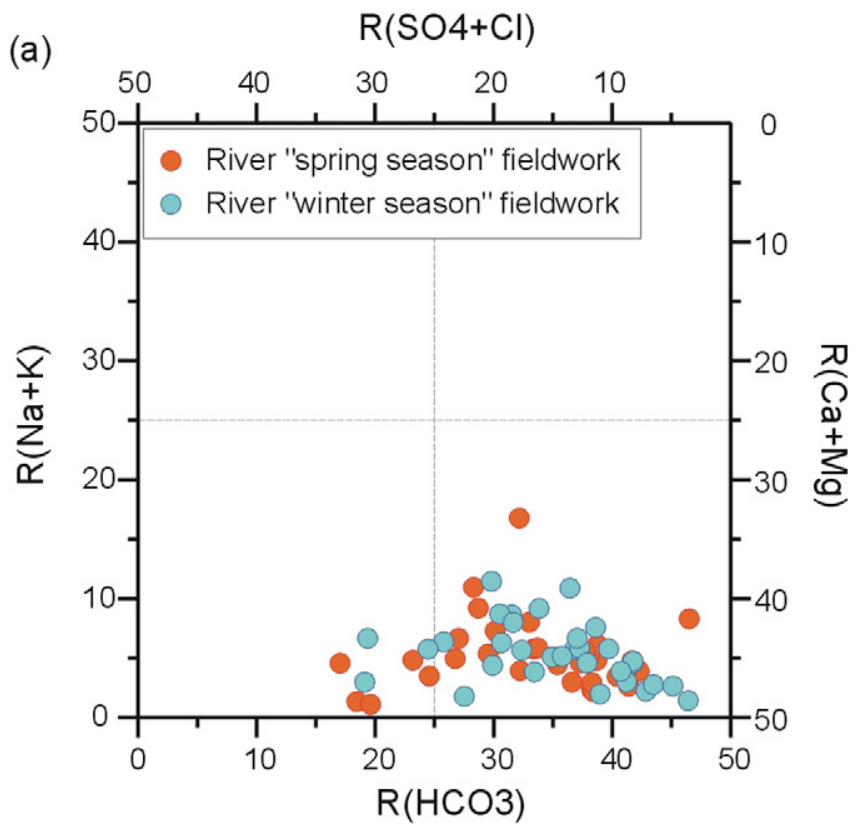

Fig. 6. Langelier-Ludwig diagram for the sampled river waters.

observed in some samples is due to the incongruent dissolution of silicate minerals, which are ubiquitous in all the studied catchments.

The presence of different sources of solutes is shown by the ${ }^{87} \mathrm{Sr} /{ }^{86} \mathrm{Sr}$ versus $\mathrm{Sr} / \mathrm{Na}$ diagram (Fig. 7) that compares the composition of sampled waters with three end-members, namely carbonate rocks, evaporates, and acid-silicate rocks, and with the average rainwater composition. Visual inspection of the diagram reveals that nearly all the samples plot between the carbonate and the evaporite end-members. A trend towards the acid silicate rocks end-member is also apparent. These observations are in good agreement with the distribution of the rock types in the study area (Table 4), and suggest that the sampled waters are a

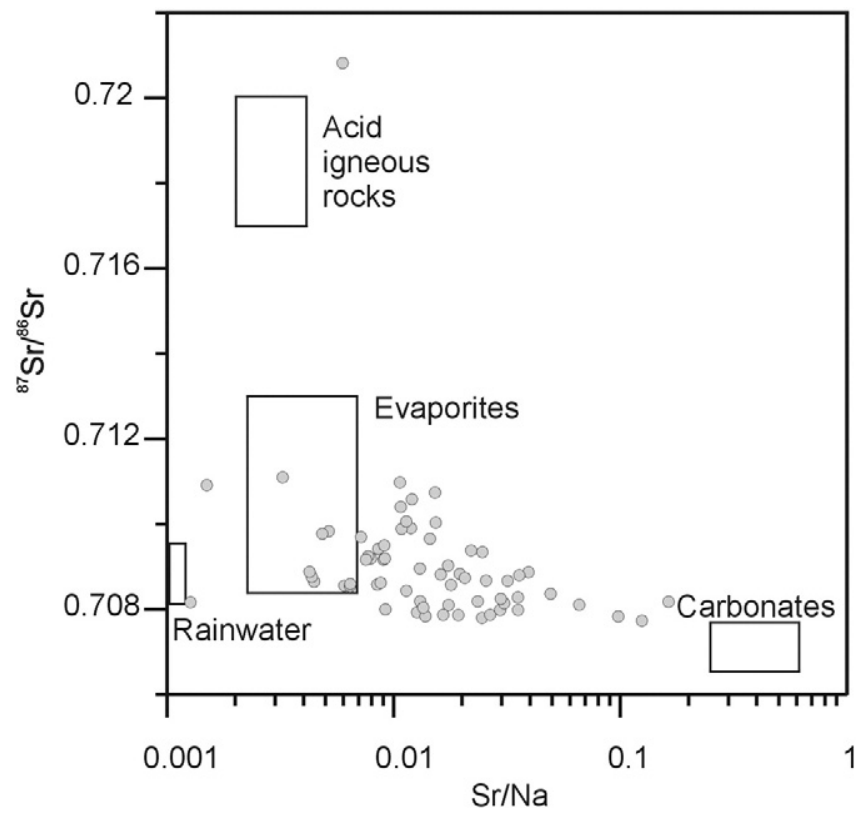

Fig. 7. ${ }^{87} \mathrm{Sr} /{ }^{86} \mathrm{Sr}$ Vs $\mathrm{Sr} / \mathrm{Na}$ molar ratio for the sampled river waters. The carbonate and silicate end members are taken from pristine French monolithological stream data (corrected for atmospheric inputs) published by Meybeck (1986), the rain water end member is taken from Roy et al. (1999), and the evaporite end member is based on two headwater samples of the Chang Jiang Tibetan river (Noh et al., 2009). 
highly representative of the water-rock interactions in the Alpine catchments.

\subsection{Representativity of the geochemical dataset}

The chemical composition of each sample analysed in this work represent the composition of a specific river at the date of sampling. In order to check the representativity of our dataset, our analyses have been compared to the available literature data. Considering that Eqs. (7) and (8) used for the computation of the fluxes request the concentrations of $\mathrm{Ca}, \mathrm{Mg}$, $\mathrm{Na}$, and $\mathrm{K}$, the concentrations of major cations analysed in this study have been compared to the mean values and standard deviations, $\sigma$, of literature data for the following rivers: Adige, Rhone, Rhine, Tagliamento, Livenza, Po, Isonzo and Ticino (Fig. 8 - Stefanini, 1976; Mosello et al., 2001; C.N.R.-I.S.E. Sezione di Idrobiologia ed Ecologia delle Acque Interne, 2004; C.N.R.-I.S.E. Sede di Verbania, 2007; Peripoli, 2008; Olivier et al., 2009; Uehlinger et al., 2009; C.N.R.-I.S.E. Sede di Verbania, 2013; Marchina et al., 2014; unpublished data from Università degli Studi di Perugia, Dipartimento di Fisica e Geologia, Perugia, Italy).

The diagrams of Fig. 8 clearly show that almost all of our data fall in the $\pm 1 \sigma$ interval (they are all comprised in the $\pm 2 \sigma$ interval) and the average values of the two campaigns are very close to the mean values of literature data (differences are limited to few concentration units).
On average the differences (in \%) between the mean concentrations of our data and the mean values obtained from literature data are: $3.9 \%$ for $\mathrm{Ca}, 13.3 \%$ for $\mathrm{Mg}, 20.8 \%$ for $\mathrm{Na}$ and $5 \%$ for $\mathrm{K}$. The average standard deviation are: $\sigma \mathrm{Ca}=18.7 \%, \sigma \mathrm{Mg}=24.1 \%$, $\sigma \mathrm{Na}=40.8 \%$ and $\sigma \mathrm{K}=33.1 \%$. These values have been used for the computation of the uncertainty on the $\mathrm{CO}_{2}$ fluxes computed with Eqs. (7) and (8).

\subsection{Solute fluxes, weathering rates, and $\mathrm{CO}_{2}$ fluxes}

For each basin, we computed (i) the flux of dissolved solids, expressed as the annual dissolved yield and given by the product of TDS concentration by runoff, (ii) the weathering rate, calculated from the difference between the dissolved solids in the stream outflow and atmospherically/ biologically derived components (assuming chloride to be conservative) multiplied by runoff, and (iii) the total atmospheric/soil $\mathrm{CO}_{2}$ flux consumed by rock weathering, calculated following the procedure described in Section 3.2.

The results of the mass balance calculations, listed in Table 6 , reveal variable values of the solute flux, weathering rate, and $\mathrm{CO}_{2}$ flux. The solute flux ranges from $8 \times 10^{3}$ to $411 \times 10^{3} \mathrm{~kg} \mathrm{~km}^{-2} \mathrm{y}^{-1}$, with an average of $127 \times 10^{3} \pm 29 \times 10^{3} \mathrm{~kg} \mathrm{~km}^{-2} \mathrm{y}^{-1}$. It is strongly correlated with $F_{\mathrm{CO} 2-\text { short }}$, but shows a weak correlation with $F_{\mathrm{CO} 2 \text {-long }}$ (Fig. 9). The weathering rate ranges from $3 \times 10^{3}$ to $339 \times 10^{3} \mathrm{~kg} \mathrm{~km}^{-2} \mathrm{y}^{-1}$,
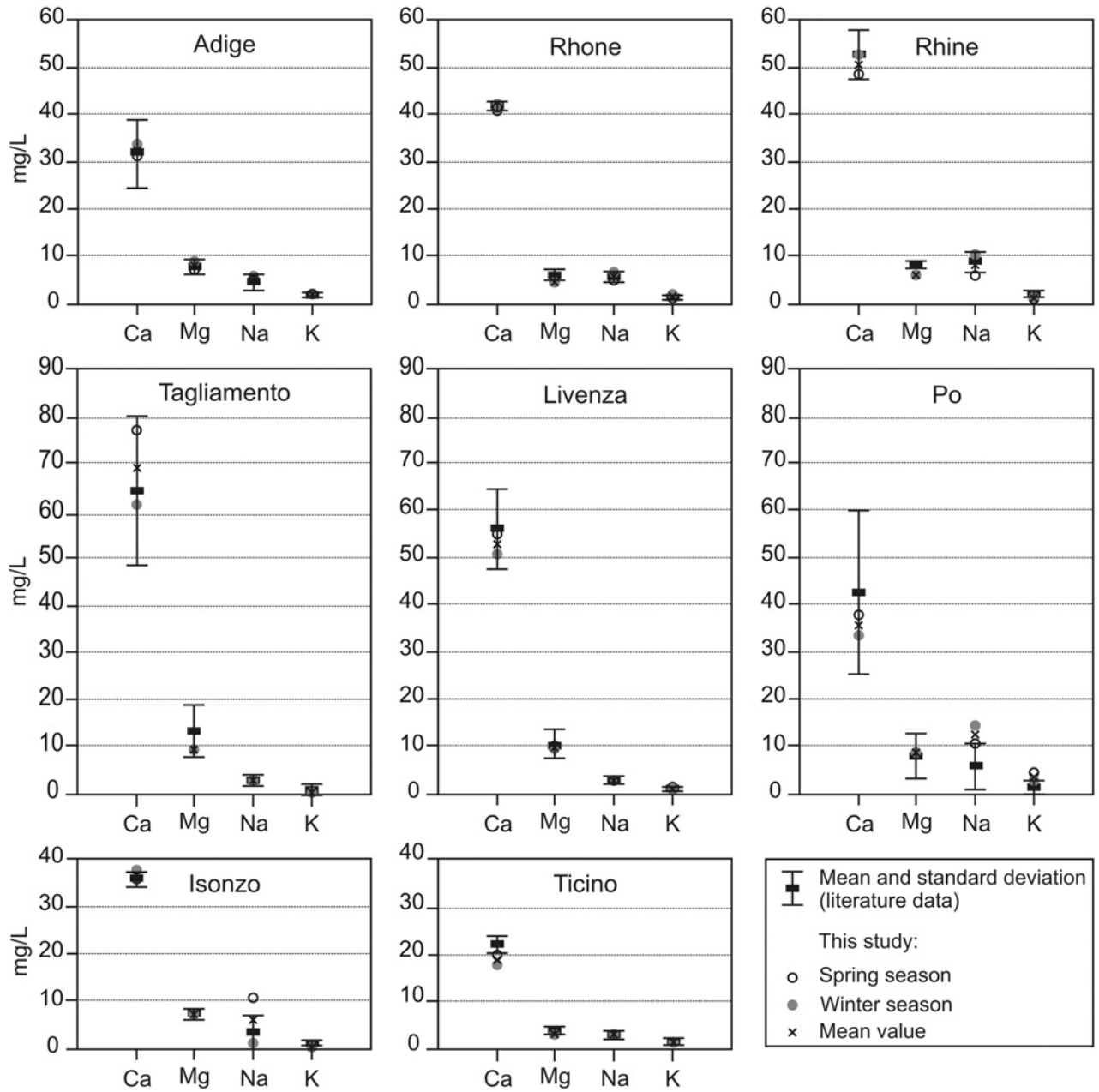

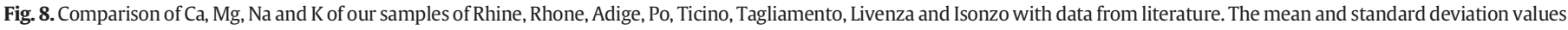

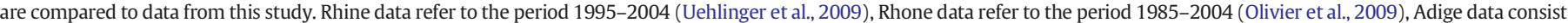

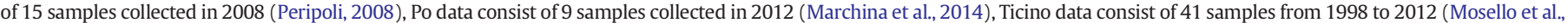

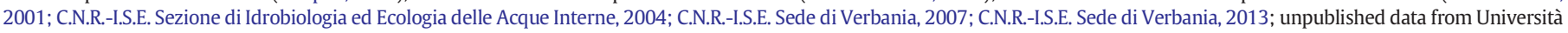
degli Studi di Perugia, Dipartimento di Fisica e Geologia, Perugia, Italy). 
Table 6

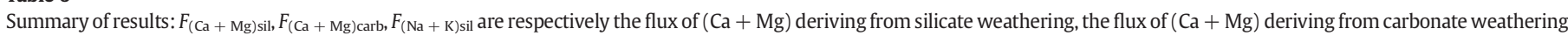

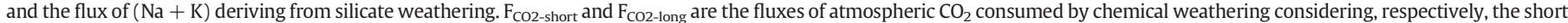
term and the long term carbon cycle. In the same table are also reported the values of flow rate, runoff, solute flux and chemical weathering.

\begin{tabular}{|c|c|c|c|c|c|c|c|c|c|c|c|}
\hline $\begin{array}{l}\text { Basin ID and } \\
\text { name }\end{array}$ & $\begin{array}{l}\text { Water } \\
\text { sample }\end{array}$ & Season & $\left.F_{(\mathrm{Ca}}+\mathrm{Mg}\right)$ sil & $\left.F_{(\mathrm{Ca}}+\mathrm{Mg}\right) \mathrm{carb}$ & $\left.F_{(\mathrm{Na}}+\mathrm{K}\right)$ sil & $F_{\text {CO2-short }}$ & $F_{\text {CO2-long }}$ & $\begin{array}{l}\text { Flow } \\
\text { rate }\end{array}$ & Runoff & $\begin{array}{l}\text { Solute } \\
\text { flux }\end{array}$ & $\begin{array}{l}\text { Chemical } \\
\text { weathering } \\
\text { rate }\end{array}$ \\
\hline & & & $\mathrm{mol} \mathrm{y}^{-1} \mathrm{~km}^{-1}$ & $\mathrm{~mol} \mathrm{y}^{-1} \mathrm{~km}^{-1}$ & $\mathrm{~mol} \mathrm{y}^{-1} \mathrm{~km}^{-1}$ & $\mathrm{~mol} \mathrm{y}^{-1} \mathrm{~km}^{-1}$ & $\mathrm{~mol} \mathrm{y}^{-1} \mathrm{~km}^{-1}$ & $\mathrm{~m}^{3} \mathrm{~s}^{-1}$ & $1 \mathrm{~s}^{-1} \mathrm{~km}^{-1}$ & $\mathrm{t} \mathrm{km}^{-2} \mathrm{y}^{-1}$ & $\mathrm{t} \mathrm{km}^{-2} \mathrm{y}^{-1}$ \\
\hline 01 - Roia & 28 & Spring & $1.35 \times 10^{4}$ & $5.74 \times 10^{5}$ & $1.10 \times 10^{4}$ & $6.12 \times 10^{5}$ & $1.35 \times 10^{4}$ & 6.67 & 10.06 & 95 & 92 \\
\hline 02 - Mella & 13 & Spring & $1.77 \times 10^{3}$ & $1.50 \times 10^{5}$ & $4.84 \times 10^{3}$ & $1.58 \times 10^{5}$ & $1.77 \times 10^{3}$ & 3.35 & 4.37 & 76 & 24 \\
\hline 03 - Brenta & 15 & Spring & $7.36 \times 10^{3}$ & $8.29 \times 10^{5}$ & $1.93 \times 10^{4}$ & $8.63 \times 10^{5}$ & $7.36 \times 10^{3}$ & 44.70 & 27.92 & 165 & 131 \\
\hline 04 - Isonzo & 19 & Spring & 0.00 & $9.08 \times 10^{5}$ & 0.00 & $9.08 \times 10^{5}$ & 0.00 & 42.00 & 26.07 & 185 & 140 \\
\hline 05 - Livenza & 17 & Spring & $3.92 \times 10^{4}$ & $2.13 \times 10^{6}$ & $3.68 \times 10^{4}$ & $2.25 \times 10^{6}$ & $3.92 \times 10^{4}$ & 76.30 & 43.11 & 411 & 339 \\
\hline 06 - Iller & 27 & Spring & $4.40 \times 10^{3}$ & $3.40 \times 10^{5}$ & $4.04 \times 10^{3}$ & $3.53 \times 10^{5}$ & $4.40 \times 10^{3}$ & 17.93 & 8.71 & 88 & 54 \\
\hline 07 - Oglio & 12 & Spring & $6.42 \times 10^{3}$ & $4.16 \times 10^{5}$ & $1.70 \times 10^{4}$ & $4.46 \times 10^{5}$ & $6.42 \times 10^{3}$ & 27.49 & 13.10 & 92 & 68 \\
\hline 08 - Sesia & 09 & Spring & $1.44 \times 10^{4}$ & $8.18 \times 104$ & $1.74 \times 10^{4}$ & $1.28 \times 10^{5}$ & $1.44 \times 10^{4}$ & 43.51 & 18.93 & 107 & 17 \\
\hline 09 - Tagliamento & 18 & Spring & $8.22 \times 10^{3}$ & $6.12 \times 10^{5}$ & $1.05 \times 10^{4}$ & $6.39 \times 10^{5}$ & $8.22 \times 10^{3}$ & 20.51 & 8.88 & 97 & 98 \\
\hline $10-$ Var & 29 & Spring & $4.49 \times 10^{3}$ & $3.75 \times 10^{5}$ & $4.09 \times 10^{3}$ & $3.88 \times 10^{5}$ & $4.49 \times 10^{3}$ & 29.10 & 10.42 & 95 & 59 \\
\hline 11 - Mincio & 02 & Spring & $5.69 \times 10^{2}$ & $5.32 \times 10^{4}$ & $1.55 \times 10^{3}$ & $5.59 \times 10^{4}$ & $5.69 \times 10^{2}$ & 5.19 & 1.79 & 12 & 8 \\
\hline 11 - Mincio & 03 & Spring & $4.55 \times 10^{2}$ & $4.21 \times 10^{4}$ & $1.24 \times 10^{3}$ & $4.43 \times 10^{4}$ & $4.55 \times 10^{2}$ & 5.15 & 1.77 & 10 & 7 \\
\hline 12 - Lech & 26 & Spring & $1.15 \times 10^{4}$ & $9.91 \times 10^{5}$ & $1.06 \times 10^{4}$ & $1.02 \times 10^{6}$ & $1.15 \times 10^{4}$ & 63.20 & 21.74 & 211 & 156 \\
\hline 13 - Enns & 23 & Spring & $3.96 \times 10^{3}$ & $6.97 \times 10^{5}$ & $1.08 \times 10^{4}$ & $7.16 \times 10^{5}$ & $3.96 \times 10^{3}$ & 81.96 & 25.78 & 146 & 110 \\
\hline $14-$ Mur & 22 & Spring & $1.05 \times 10^{5}$ & $1.52 \times 10^{5}$ & $2.88 \times 10^{5}$ & $6.49 \times 10^{5}$ & $1.05 \times 10^{5}$ & 44.10 & 13.65 & 79 & 76 \\
\hline 15 - Dora Baltea & 08 & Spring & $2.99 \times 10^{3}$ & $4.02 \times 10^{5}$ & $4.93 \times 10^{3}$ & $4.13 \times 10^{5}$ & $2.99 \times 10^{3}$ & 64.60 & 18.13 & 104 & 63 \\
\hline 16 - Piave & 16 & Spring & $9.47 \times 10^{3}$ & $4.10 \times 10^{5}$ & $1.17 \times 10^{4}$ & $4.40 \times 10^{5}$ & $9.47 \times 10^{3}$ & 42.44 & 9.23 & 80 & 66 \\
\hline 17 - Adda & 11 & Spring & $2.16 \times 10^{4}$ & $4.39 \times 10^{5}$ & $4.03 \times 10^{4}$ & $5.22 \times 10^{5}$ & $2.16 \times 10^{4}$ & 110.80 & 23.54 & 113 & 76 \\
\hline $18-$ Ticino & 10 & Spring & $4.63 \times 10^{4}$ & $4.59 \times 10^{5}$ & $6.03 \times 10^{4}$ & $6.12 \times 10^{5}$ & $4.63 \times 10^{4}$ & 248.00 & 37.50 & 134 & 87 \\
\hline 19 - Isar & 25 & Spring & $5.20 \times 10^{3}$ & $2.61 \times 10^{5}$ & $4.63 \times 10^{3}$ & $2.76 \times 10^{5}$ & $5.20 \times 10^{3}$ & 46.80 & 6.00 & 83 & 42 \\
\hline 20 - Tanaro & 06 & Spring & $1.38 \times 10^{4}$ & $3.79 \times 10^{5}$ & $1.02 \times 10^{4}$ & $4.16 \times 10^{5}$ & $1.38 \times 10^{4}$ & 121.00 & 14.79 & 161 & 62 \\
\hline 21 - Sava & 20 & Spring & $1.83 \times 10^{4}$ & $5.12 \times 10^{5}$ & $1.74 \times 10^{4}$ & $5.66 \times 10^{5}$ & $1.83 \times 10^{4}$ & 105.74 & 12.68 & 117 & 84 \\
\hline $22-$ Po & 07 & Spring & $6.96 \times 10^{3}$ & $1.27 \times 10^{5}$ & $5.64 \times 10^{3}$ & $1.47 \times 10^{5}$ & $6.96 \times 10^{3}$ & 80.30 & 8.87 & 68 & 21 \\
\hline 23 - Adige & 14 & Spring & $7.75 \times 10^{3}$ & $3.46 \times 10^{5}$ & $1.72 \times 10^{4}$ & $3.78 \times 10^{5}$ & $7.75 \times 10^{3}$ & 158.77 & 15.57 & 94 & 57 \\
\hline 24 - Drava & 21 & Spring & $6.31 \times 10^{3}$ & $2.83 \times 10^{5}$ & $1.73 \times 10^{4}$ & $3.13 \times 10^{5}$ & $6.31 \times 10^{3}$ & 110.17 & 10.50 & 67 & 47 \\
\hline 25 - Rhone & 32 & Spring & $5.63 \times 10^{3}$ & $5.59 \times 10^{5}$ & $5.97 \times 10^{3}$ & $5.76 \times 10^{5}$ & $5.63 \times 10^{3}$ & 233.00 & 22.28 & 148 & 88 \\
\hline 26 - Isere & 31 & Spring & $1.70 \times 10^{4}$ & $1.19 \times 10^{6}$ & $8.16 \times 10^{3}$ & $1.23 \times 10^{6}$ & $1.70 \times 10^{4}$ & 377.06 & 33.74 & 275 & 188 \\
\hline 27 - Durance & 30 & Spring & $4.81 \times 10^{2}$ & $3.27 \times 10^{4}$ & $3.89 \times 10^{2}$ & $3.41 \times 10^{4}$ & $4.81 \times 10^{2}$ & 9.26 & 0.77 & 8 & 5 \\
\hline $28-\operatorname{Inn}$ & 24 & Spring & $3.93 \times 10^{3}$ & $5.95 \times 10^{5}$ & $7.15 \times 10^{3}$ & $6.10 \times 10^{5}$ & $3.93 \times 10^{3}$ & 450.21 & 18.91 & 164 & 93 \\
\hline 29 - Rhine & 33 & Spring & $2.98 \times 10^{3}$ & $4.72 \times 10^{5}$ & $4.49 \times 10^{3}$ & $4.83 \times 10^{5}$ & $2.98 \times 10^{3}$ & 564.00 & 15.35 & 123 & 74 \\
\hline 01 - Roia & 55 & Winter & $2.74 \times 10^{4}$ & $4.09 \times 10^{5}$ & $2.22 \times 10^{4}$ & $4.86 \times 10^{5}$ & $2.74 \times 10^{4}$ & 3.38 & 5.10 & 77 & 73 \\
\hline 02 - Mella & 41 & Winter & $8.70 \times 10^{3}$ & $2.33 \times 10^{5}$ & $2.38 \times 10^{4}$ & $2.74 \times 10^{5}$ & $8.70 \times 10^{3}$ & 7.80 & 10.17 & 168 & 40 \\
\hline 03 - Brenta & 43 & Winter & $7.16 \times 10^{3}$ & $9.06 \times 10^{5}$ & $1.88 \times 10^{4}$ & $9.39 \times 10^{5}$ & $7.16 \times 10^{3}$ & 42.30 & 26.39 & 193 & 143 \\
\hline 04 - Isonzo & 47 & Winter & 0.00 & $1.65 \times 10^{6}$ & 0.00 & $1.65 \times 10^{6}$ & 0.00 & 73.10 & 45.38 & 327 & 254 \\
\hline 05 - Livenza & 45 & Winter & $2.25 \times 10^{4}$ & $8.46 \times 10^{5}$ & $2.11 \times 10^{4}$ & $9.12 \times 10^{5}$ & $2.25 \times 10^{4}$ & 32.40 & 18.31 & 161 & 137 \\
\hline 06 - Iller & 65 & Winter & 0.00 & $6.66 \times 10^{5}$ & 0.00 & $6.66 \times 10^{5}$ & 0.00 & 36.50 & 17.74 & 216 & 103 \\
\hline 07 - Oglio & 40 & Winter & $1.18 \times 10^{4}$ & $6.31 \times 10^{5}$ & $3.13 \times 10^{4}$ & $6.86 \times 10^{5}$ & $1.18 \times 10^{4}$ & 46.05 & 21.94 & 128 & 103 \\
\hline 08 - Sesia & 37 & Winter & $6.70 \times 10^{3}$ & $4.67 \times 10^{4}$ & $8.11 \times 10^{3}$ & $6.82 \times 10^{4}$ & $6.70 \times 10^{3}$ & 7.30 & 3.18 & 22 & 9 \\
\hline 09 - Tagliamento & 46 & Winter & $3.85 \times 10^{4}$ & $1.76 \times 10^{6}$ & $4.93 \times 10^{4}$ & $1.88 \times 10^{6}$ & $3.85 \times 10^{4}$ & 73.72 & 31.93 & 327 & 287 \\
\hline $10-\operatorname{Var}$ & 56 & Winter & $4.53 \times 10^{4}$ & $3.26 \times 10^{5}$ & $4.12 \times 10^{4}$ & $4.58 \times 10^{5}$ & $4.53 \times 10^{4}$ & 20.10 & 7.19 & 106 & 64 \\
\hline 11 - Mincio & 42 & Winter & $2.93 \times 10^{2}$ & $3.85 \times 10^{4}$ & $8.00 \times 10^{2}$ & $3.99 \times 10^{4}$ & $2.93 \times 10^{2}$ & 4.89 & 1.68 & 9 & 6 \\
\hline 12 - Lech & 66 & Winter & $7.43 \times 10^{4}$ & 1. $78 \times 10^{6}$ & $6.83 \times 10^{4}$ & $1.99 \times 10^{6}$ & $7.43 \times 10^{4}$ & 112.00 & 38.53 & 409 & 293 \\
\hline 13 - Enns & 51 & Winter & $1.32 \times 10^{3}$ & $3.04 \times 10^{5}$ & $3.62 \times 10^{3}$ & $3.10 \times 10^{5}$ & $1.32 \times 10^{3}$ & 36.88 & 11.60 & 89 & 48 \\
\hline $14-$ Mur & 50 & Winter & $2.61 \times 10^{4}$ & $1.25 \times 10^{5}$ & $7.15 \times 10^{4}$ & $2.49 \times 10^{5}$ & $2.61 \times 10^{4}$ & 25.80 & 7.99 & 62 & 32 \\
\hline 15 - Dora Baltea & 36 & Winter & $1.07 \times 10^{4}$ & $3.55 \times 10^{5}$ & $1.77 \times 10^{4}$ & $3.94 \times 10^{5}$ & $1.07 \times 10^{4}$ & 42.30 & 11.87 & 78 & 59 \\
\hline 16 - Piave & 44 & Winter & $6.02 \times 10^{3}$ & $2.32 \times 10^{5}$ & $7.46 \times 10^{3}$ & $2.52 \times 10^{5}$ & $6.02 \times 10^{3}$ & 25.96 & 5.65 & 51 & 38 \\
\hline 17 - Adda & 39 & Winter & $3.17 \times 10^{4}$ & $5.40 \times 10^{5}$ & $5.90 \times 10^{4}$ & $6.63 \times 10^{5}$ & $3.17 \times 10^{4}$ & 145.60 & 30.93 & 131 & 96 \\
\hline 18 - Ticino & 38 & Winter & $3.82 \times 10^{4}$ & $3.30 \times 10^{5}$ & $4.97 \times 10^{4}$ & $4.56 \times 10^{5}$ & $3.82 \times 10^{4}$ & 185.00 & 27.97 & 85 & 64 \\
\hline 19 - Isar & 53 & Winter & $3.55 \times 10^{3}$ & $1.17 \times 10^{5}$ & $3.16 \times 10^{3}$ & $1.27 \times 10^{5}$ & $3.55 \times 10^{3}$ & 32.50 & 4.17 & 58 & 19 \\
\hline 20 - Tanaro & 34 & Winter & $3.70 \times 10^{4}$ & $1.51 \times 10^{5}$ & $2.74 \times 10^{4}$ & $2.53 \times 10^{5}$ & $3.70 \times 10^{4}$ & 61.00 & 7.46 & 91 & 32 \\
\hline 21 - Sava & 48 & Winter & $1.60 \times 10^{4}$ & $3.98 \times 10^{5}$ & $1.52 \times 10^{4}$ & $4.45 \times 10^{5}$ & $1.60 \times 10^{4}$ & 95.03 & 11.40 & 109 & 65 \\
\hline $22-\mathrm{Po}$ & 35 & Winter & $3.43 \times 10^{4}$ & $2.17 \times 10^{4}$ & $2.78 \times 10^{4}$ & $1.18 \times 10^{5}$ & $3.43 \times 10^{4}$ & 58.90 & 6.50 & 48 & 11 \\
\hline 23 - Adige & 54 & Winter & $7.87 \times 10^{3}$ & $2.58 \times 10^{5}$ & $1.75 \times 10^{4}$ & $2.91 \times 10^{5}$ & $7.87 \times 10^{3}$ & 102.68 & 10.07 & 67 & 43 \\
\hline 24 - Drava & 49 & Winter & $7.46 \times 10^{3}$ & $1.79 \times 10^{5}$ & $2.05 \times 10^{4}$ & $2.15 \times 10^{5}$ & $7.46 \times 10^{3}$ & 66.38 & 6.33 & 46 & 31 \\
\hline 25 - Rhone & 59 & Winter & $1.53 \times 10^{4}$ & $7.03 \times 10^{5}$ & $1.62 \times 10^{4}$ & $7.49 \times 10^{5}$ & $1.53 \times 10^{4}$ & 333.00 & 31.84 & 220 & 112 \\
\hline 26 - Isere & 58 & Winter & $1.02 \times 10^{5}$ & $7.64 \times 10^{5}$ & $4.90 \times 10^{4}$ & $1.02 \times 10^{6}$ & $1.02 \times 10^{5}$ & 212.95 & 19.06 & 238 & 140 \\
\hline 27 - Durance & 57 & Winter & $2.42 \times 10^{3}$ & $1.58 \times 10^{4}$ & $1.96 \times 10^{3}$ & $2.26 \times 10^{4}$ & $2.42 \times 10^{3}$ & 8.20 & 0.68 & 8 & 3 \\
\hline $28-\operatorname{Inn}$ & 52 & Winter & $2.06 \times 10^{3}$ & $2.61 \times 10^{5}$ & $3.74 \times 10^{3}$ & $2.69 \times 10^{5}$ & $2.06 \times 10^{3}$ & 218.73 & 9.19 & 82 & 41 \\
\hline 29 - Rhine & 61 & Winter & $3.01 \times 10^{4}$ & $4.98 \times 10^{5}$ & $4.55 \times 10^{4}$ & $6.04 \times 10^{5}$ & $3.01 \times 10^{4}$ & 708.00 & 19.27 & 172 & 87 \\
\hline 30 - Linth & 63 & Winter & $2.27 \times 10^{4}$ & $1.01 \times 10^{6}$ & $5.80 \times 10^{4}$ & $1.11 \times 10^{6}$ & $2.27 \times 10^{4}$ & 61.18 & 33.73 & 240 & 167 \\
\hline 31 - Reuss & 62 & Winter & $1.57 \times 10^{4}$ & $5.14 \times 10^{5}$ & $2.39 \times 10^{4}$ & $5.69 \times 10^{5}$ & $1.57 \times 10^{4}$ & 53.40 & 18.81 & 102 & 84 \\
\hline 32 - Alpine Rhine & 64 & Winter & $5.50 \times 10^{2}$ & $4.75 \times 10^{4}$ & $1.06 \times 10^{3}$ & $4.96 \times 10^{4}$ & $5.50 \times 10^{2}$ & 9.51 & 1.23 & 10 & 8 \\
\hline 33 - Aare & 60 & Winter & $7.21 \times 10^{3}$ & $7.49 \times 10^{5}$ & $1.59 \times 10^{4}$ & $7.79 \times 10^{5}$ & $7.21 \times 10^{3}$ & 175.77 & 21.22 & 184 & 119 \\
\hline 34 - Rhine-Basel & $\mathrm{a}$ & Winter & $5.90 \times 10^{4}$ & $5.24 \times 10^{5}$ & $8.44 \times 10^{4}$ & $7.29 \times 10^{5}$ & $5.90 \times 10^{4}$ & 408.14 & 25.35 & 248 & 99.9 \\
\hline
\end{tabular}

a For the computation of the fluxes of sub-basin 34 , has been used the composition of sample 61 after subtraction of the mean, weighted on discharge, of samples $60,62,63$ and 64 .

with an average of $83 \times 10^{3} \pm 16 \times 10^{3} \mathrm{~kg} \mathrm{~km}^{-2} \mathrm{y}^{-1}$, and is always lower than the solute flux, because the latter comprises the atmospheric and biologic components.
During the "spring season" the fluxes of $\mathrm{CO}_{2}$ consumed by rock weathering $\left(F_{\mathrm{CO} 2 \text {-short }}\right)$ ranges form $2.60 \times 10^{4} \mathrm{~mol} \mathrm{~km}^{-2} \mathrm{y}^{-1}$ (Durance) to $2.03 \times 10^{6} \mathrm{~mol} \mathrm{~km} \mathrm{~km}^{-2} \mathrm{y}^{-1}$ (Livenza), with an average of 

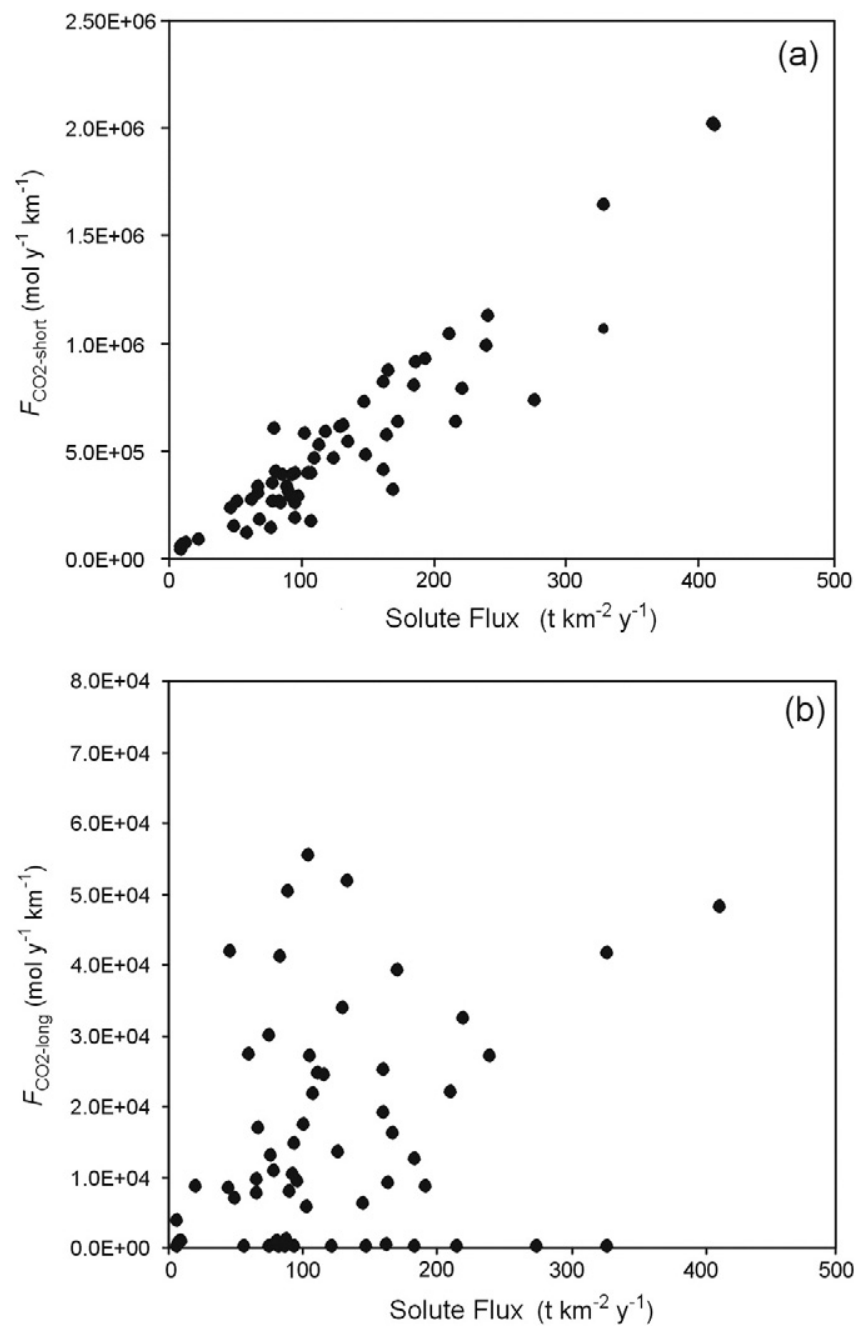

Fig. 9. Comparison between flux of solute flux and $F_{\mathrm{CO} 2}$ considering (a) the short-term carbon cycle and (b) the long-term carbon cycle.

$4.69 \times 10^{5} \pm 1.03 \times 10^{5} \mathrm{~mol} \mathrm{~km}^{-2} \mathrm{y}^{-1}$, whereas in the "winter season" they range from $2.48 \times 10^{4}$ (Durance) to $2.04 \times 10^{6} \mathrm{~mol} \mathrm{~km}^{-2} \mathrm{y}^{-1}$ (Lech), with an average of $5.35 \times 10^{5} \pm 0.97 \times 10^{5} \mathrm{~mol} \mathrm{~km}^{-2} \mathrm{y}^{-1}$. The average value of $F_{\mathrm{CO} 2 \text {-short }}$ considering all the measurements is $5.03 \times 10^{5} \pm$ $1.00 \times 10^{5} \mathrm{~mol} \mathrm{~km}^{-2} \mathrm{y}^{-1}$, and the total amount of $\mathrm{CO}_{2}$ consumed by short-term weathering is $9.42 \times 10^{10} \pm 1.88 \times 10^{10} \mathrm{~mol} \mathrm{y}^{-1}$.

If we consider the long-term carbon cycle, the net amount of atmospheric $\mathrm{CO}_{2}$ fixed by weathering is more than one order of magnitude lower, with a mean value of $F_{\mathrm{CO} 2 \text {-long }}=2.01 \times 10^{4} \pm$ $0.41 \times 10^{4} \mathrm{~mol} \mathrm{~km}^{-2} \mathrm{y}^{-1}$, and a total amount of $\mathrm{CO}_{2}$ fixed of by long-term weathering of $4.03 \times 10^{9} \pm 0.79 \times 10^{9} \mathrm{~mol} \mathrm{y}^{-1}$. The estimated long-term $\mathrm{CO}_{2}$ fluxes show a very large variability from basin to basin and range form $0.00 \mathrm{~mol} \mathrm{~km}^{-2} \mathrm{y}^{-1}$ (Rhein, Rhone, Isere, Durance, Var, Iller, Isar, Isonzo and Mella) to $1.06 \times 10^{5} \mathrm{~mol} \mathrm{~km}^{-2} \mathrm{y}^{-1}$ (Mur), with an average value of $1.43 \times 10^{4} \pm 0.30 \times 10^{4} \mathrm{~mol} \mathrm{~km}^{-2} \mathrm{y}^{-1}$, during the "spring season", while during the "winter season" it varies from $0.00 \mathrm{~mol} \mathrm{~km}^{-2} \mathrm{y}^{-1}$ (Isonzo, Isar and Iller) to $1.45 \times 10^{5} \mathrm{~mol} \mathrm{~km}^{-2} \mathrm{y}^{-1}$ (Isere), with an average value of $2.54 \times 10^{4} \pm 0.51 \times 10^{4} \mathrm{~mol} \mathrm{~m}^{-2} \mathrm{y}^{-1}$.

\section{Discussion}

For most of the considered basins, the $\mathrm{CO}_{2}$ consumed by weathering is slightly higher in the winter than in the spring, but the variations are limited. Conversely, the differences observed comparing different basins are large, with the values of $F_{\mathrm{CO} 2 \text {-short }}$ ranging over two orders of magnitude, and the values of $F_{\mathrm{CO} 2 \text {-long }}$ ranging over five orders of magnitude.

The comparison between the $F_{\mathrm{CO} 2 \text {-long }}$ and the $F_{\mathrm{CO} 2 \text {-short }}$ values indicates that the $\mathrm{CO}_{2}$ removed from the atmosphere/soil system in the long-term $(>1 \mathrm{Ma})$ is significantly smaller than the $\mathrm{CO}_{2}$ consumed by weathering in the short-term. On average, $F_{\mathrm{CO} 2 \text {-long }}$ is $4.8 \%$ of $F_{\mathrm{CO} 2 \text {-short }}$. This indicates that $>95 \%$ of the $\mathrm{CO}_{2}$ consumed by chemical weathering is returned to the atmosphere within $1 \mathrm{Ma}$. However, it is necessary to consider that the assumptions made for the calculation of $F_{\mathrm{CO} 2 \text {-long }}$ give a minimum estimate for the long-term atmospheric $\mathrm{CO}_{2}$ removal.

To search for relationships between $F_{\mathrm{CO} 2}$ (both in the short and in the long-term) and the potential controlling factors, we considered the variables runoff, precipitation, temperature, elevation, and lithology, and we searched for possible correlations between the variables calculating the sample Pearson product-moment correlation coefficient $(\mathrm{r})$ and the Spearman's rank correlation coefficient $\left(\mathrm{r}_{\mathrm{s}}\right)$ for each pair of variables (Pearson, 1895; Spearman, 1904). Results are listed in Table $7 . F_{\mathrm{CO} 2 \text {-short }}$ is characterized by a strong correlation with runoff $\left(\mathrm{r}=0.857 ; \mathrm{r}_{\mathrm{s}}=0.883\right)$, no significant correlations with precipitation, temperature and elevation, a weak positive correlation with the percentage of carbonate rocks cropping out in the basin, and a weak negative correlation with the percentage of silicates. $F_{\mathrm{CO} 2 \text {-long }}$ exhibits a moderate correlation with runoff $\left(r=0.415 ; r_{s}=0.436\right)$, no correlation with precipitation, temperature and elevation, weak correlations with the lithological types i.e., negative correlations with carbonates, and positive correlations with silicates. Fig. 10 shows the correlation between $F_{\mathrm{CO} 2}$ and Runoff considering (a) the short-term carbon cycle and (b) the long-term carbon cycle.

To search for a functional relation linking the controlling factors and the $F_{\mathrm{CO} 2}$ values, we performed a multiple regression analysis considering as independent (explanatory) variables only the potential controlling factors that in the correlation analysis showed some degree of correlation with the $\mathrm{CO}_{2}$ flux (Table 7), that is runoff and the percentages of carbonates, Na-K silicates, and $\mathrm{Ca}-\mathrm{Mg}$ silicates. We obtained two regression equations, for the short-term and the long-term $\mathrm{CO}_{2}$ flux. The equations are

$$
\begin{aligned}
F_{\text {CO2-short }}= & 3143.75 \times \mathrm{X}_{1}+336.71 \times \mathrm{X}_{2}-5608.00 \times \mathrm{X}_{3} \\
& +2335.76 \times \mathrm{X}_{4}+37,182.96,
\end{aligned}
$$

with a rss $=2.7 \times 10^{12}$, and

$$
\begin{aligned}
F_{\text {CO2-long }}= & 71.85 \times \mathrm{X}_{1}-31.22 \times \mathrm{X}_{2}+284.18 \times \mathrm{X}_{3}+153.29 \\
& \times \mathrm{X}_{4}-2293.10
\end{aligned}
$$

with a rss $=2.41 \times 10^{10}$, where $F_{\mathrm{CO} 2-s h o r t}$ and $F_{\mathrm{CO} 2 \text {-long }}$ are the $\mathrm{CO}_{2}$ fluxes in $\mathrm{mol} \mathrm{km}^{-2} \mathrm{y}^{-1}, \mathrm{X}_{1}$ is runoff in $1 \mathrm{~s}^{-1} \mathrm{~km}^{-1}, \mathrm{X}_{2}, \mathrm{X}_{3}$ and $\mathrm{X}_{4}$ are the percentages of carbonates, $\mathrm{Na}-\mathrm{K}$ silicates, and $\mathrm{Ca}-\mathrm{Mg}$ silicates cropping out in each basin, respectively, while rss is the regression sum of square.

The results of the multiple regression modelling reveals a very good correlation between the values of $F_{\mathrm{CO} 2 \text {-short }}$ computed from the multiple regression on controlling factors and the values derived from the application of the geochemical model (Fig. 11a). This suggests that in the Alps the main factor controlling the $\mathrm{CO}_{2}$ consumption is runoff, and to a lesser extent lithology. The average value of $F_{\mathrm{CO} 2 \text {-short }}$ obtained by the regression model $\left(4.93 \times 10^{5} \mathrm{~mol} \mathrm{~km} \mathrm{~kg}^{-2} \mathrm{y}^{-1}\right)$ is very close to value obtained by the geochemical model $\left(5.03 \times 10^{5} \mathrm{~mol} \mathrm{~km}^{-2} \mathrm{y}^{-1}\right)$, and it's a further confirmation of the reliability of our data, considering that the two models are based on two independent sets of runoff data. The clear correlation between $F_{\text {CO2-short }}$ and runoff is in a good agreement with Kump et al. (2000), and indicates an important dependence of chemical erosion rates and $\mathrm{CO}_{2}$ fluxes on the intensity of the hydrological cycle.

On the contrary, as expected from the correlation analysis, the values of $F_{\mathrm{CO} 2-\text { long }}$ obtained by the regression model do not correlate well with the values obtained by the geochemical model (Fig. 11b). 
Table 7

Correlations between $F_{\mathrm{CO} 2}$, and controlling factors: (a) Pearson product-moment correlation coefficients and (b) Spearman's correlation coefficients

\begin{tabular}{|c|c|c|c|c|c|c|c|c|c|}
\hline & $F_{\mathrm{CO} 2 \text {-short }}$ & $F_{\mathrm{CO} 2 \text {-long }}$ & Runoff & Precipitation & Temperature & Elevation & $\%$ carbonate rocks & $\% \mathrm{Na}-\mathrm{K}$ silicates & \% Ca-Mg silicates \\
\hline \multicolumn{10}{|c|}{ Pearson correlation matrix } \\
\hline$F_{\mathrm{CO} 2 \text {-short }}$ & 1.000 & 0.415 & 0.857 & 0.053 & 0.069 & 0.098 & 0.258 & -0.345 & -0.151 \\
\hline$F_{\mathrm{CO} 2 \text {-long }}$ & 0.415 & 1.000 & 0.359 & 0.034 & -0.008 & -0.139 & -0.346 & 0.335 & 0.347 \\
\hline Runoff & 0.857 & 0.359 & 1.000 & 0.303 & -0.115 & 0.011 & 0.239 & -0.263 & -0.190 \\
\hline Precipitation & 0.053 & 0.034 & 0.303 & 1.000 & -0.805 & 0.554 & 0.204 & -0.056 & -0.312 \\
\hline Temperature & 0.069 & -0.008 & -0.115 & -0.805 & 1.000 & -0.659 & -0.097 & -0.060 & 0.225 \\
\hline Elevation & 0.098 & -0.139 & 0.011 & 0.554 & -0.659 & 1.000 & -0.406 & 0.508 & 0.267 \\
\hline$\%$ carbonate rocks & 0.258 & -0.346 & 0.239 & 0.204 & -0.097 & -0.406 & 1.000 & -0.929 & -0.944 \\
\hline$\% \mathrm{Na}-\mathrm{K}$ silicates & -0.345 & 0.335 & -0.263 & -0.056 & -0.060 & 0.508 & -0.929 & 1.000 & 0.758 \\
\hline$\%$ Ca-Mg silicates & -0.151 & 0.347 & -0.190 & -0.312 & 0.225 & 0.267 & -0.944 & 0.758 & 1.000 \\
\hline \multicolumn{10}{|c|}{ Spearman correlation matrix } \\
\hline$F_{\text {CO2-short }}$ & 1.000 & 0.436 & 0.883 & 0.182 & -0.099 & -0.032 & 0.271 & -0.321 & -0.270 \\
\hline$F_{\mathrm{CO} 2 \text {-long }}$ & 0.436 & 1.000 & 0.384 & -0.002 & 0.189 & 0.040 & -0.182 & 0.141 & 0.201 \\
\hline Runoff & 0.883 & 0.384 & 1.000 & 0.343 & -0.171 & 0.428 & 0.267 & -0.281 & -0.262 \\
\hline Precipitation & 0.182 & -0.002 & 0.343 & 1.000 & -0.777 & 0.587 & 0.184 & -0.054 & -0.243 \\
\hline Temperature & -0.099 & 0.189 & -0.171 & -0.777 & 1.000 & -0.608 & -0.135 & 0.017 & 0.208 \\
\hline Elevation & -0.032 & 0.040 & 0.428 & 0.587 & -0.608 & 1.000 & -0.425 & 0.531 & 0.351 \\
\hline$\%$ carbonate rocks & 0.271 & -0.182 & 0.267 & 0.184 & -0.135 & -0.425 & 1.000 & -0.956 & -0.975 \\
\hline$\% \mathrm{Na}-\mathrm{K}$ silicates & -0.321 & 0.141 & -0.281 & -0.054 & 0.017 & 0.531 & -0.956 & 1.000 & 0.890 \\
\hline \% Ca-Mg silicates & -0.270 & 0.201 & -0.262 & -0.243 & 0.208 & 0.351 & -0.975 & 0.890 & 1.000 \\
\hline
\end{tabular}
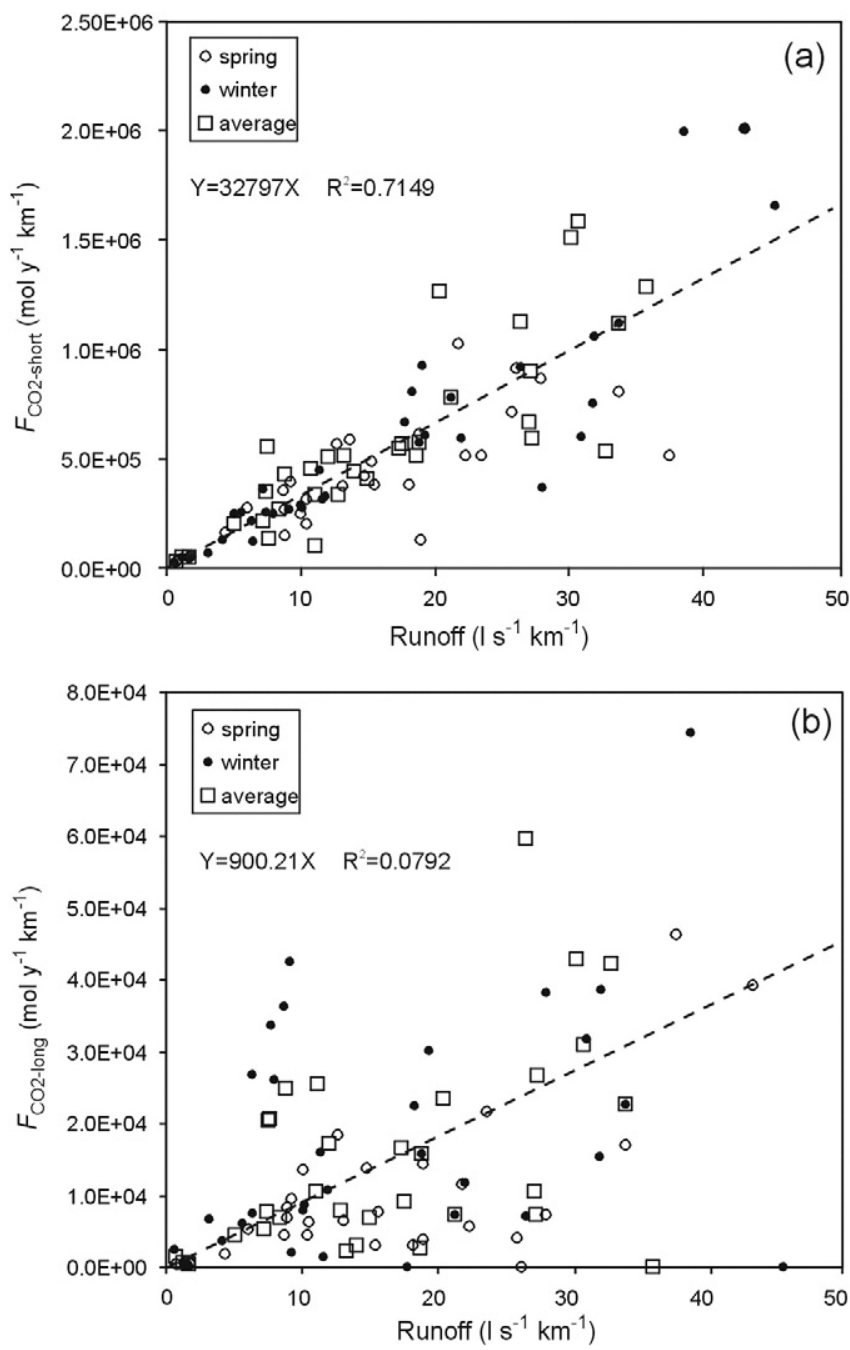

Fig. 10. Correlation between $F_{\mathrm{CO} 2}$ and Runoff considering (a) the short-term carbon cycle and (b) the long-term carbon cycle. The regression lines are obtained considering intercept $=0$.
The average value for the $F_{\mathrm{CO} 2 \text {-long }}$ obtained using the regression model $\left(1.50 \times 10^{4} \mathrm{~mol} \mathrm{~km}^{-2} \mathrm{y}^{-1}\right)$ and the geochemical model $\left(2.01 \times 10^{4} \mathrm{~mol} \mathrm{~km}^{-2} \mathrm{y}^{-1}\right)$ are similar.

Considering the good correlation of $F_{\mathrm{CO} 2 \text {-short }}$ with the controlling factors, we computed from Eq. (12) the values of the short-term $\mathrm{CO}_{2}$
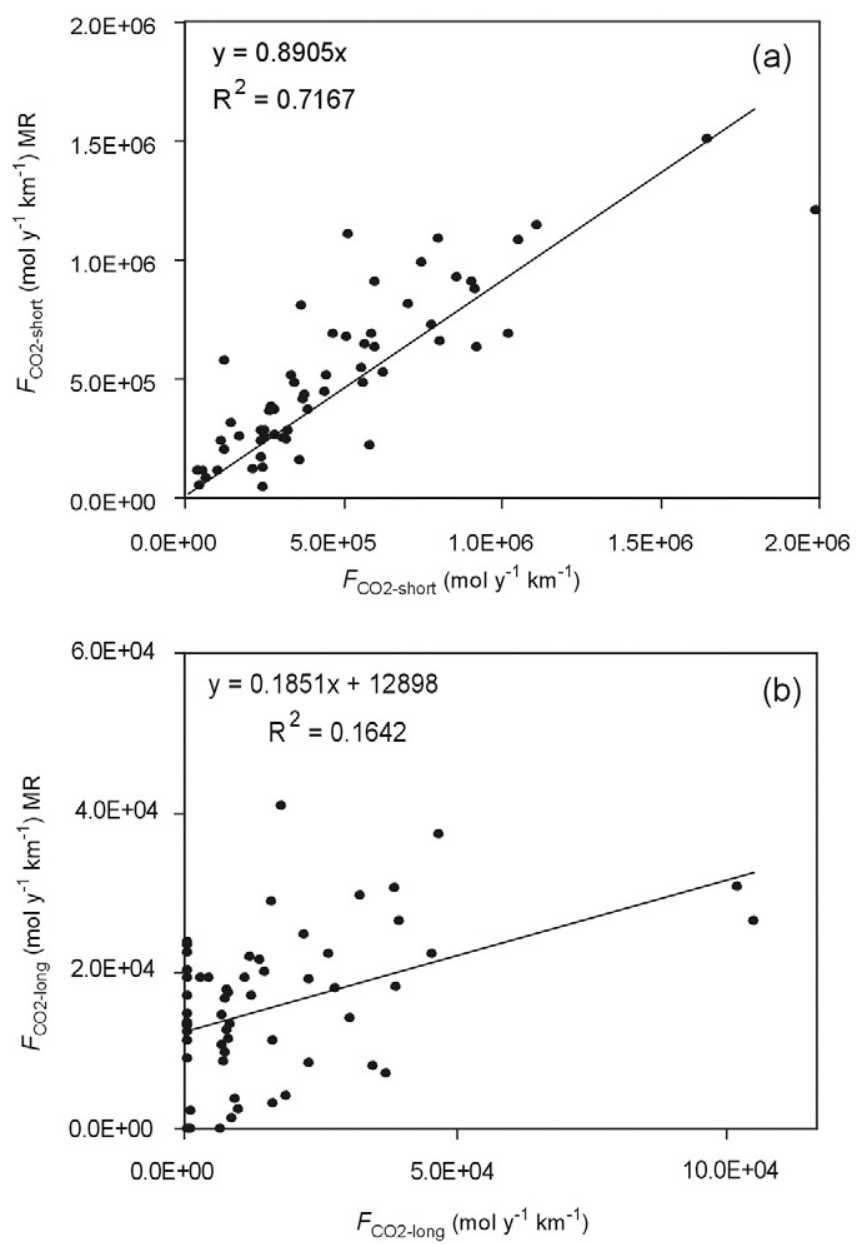

Fig. 11. Comparison between $F_{\mathrm{CO} 2}$ derived from chemical analyses and $F_{\mathrm{CO} 2}$ computed through the multiple regression analyses on controlling factors. 


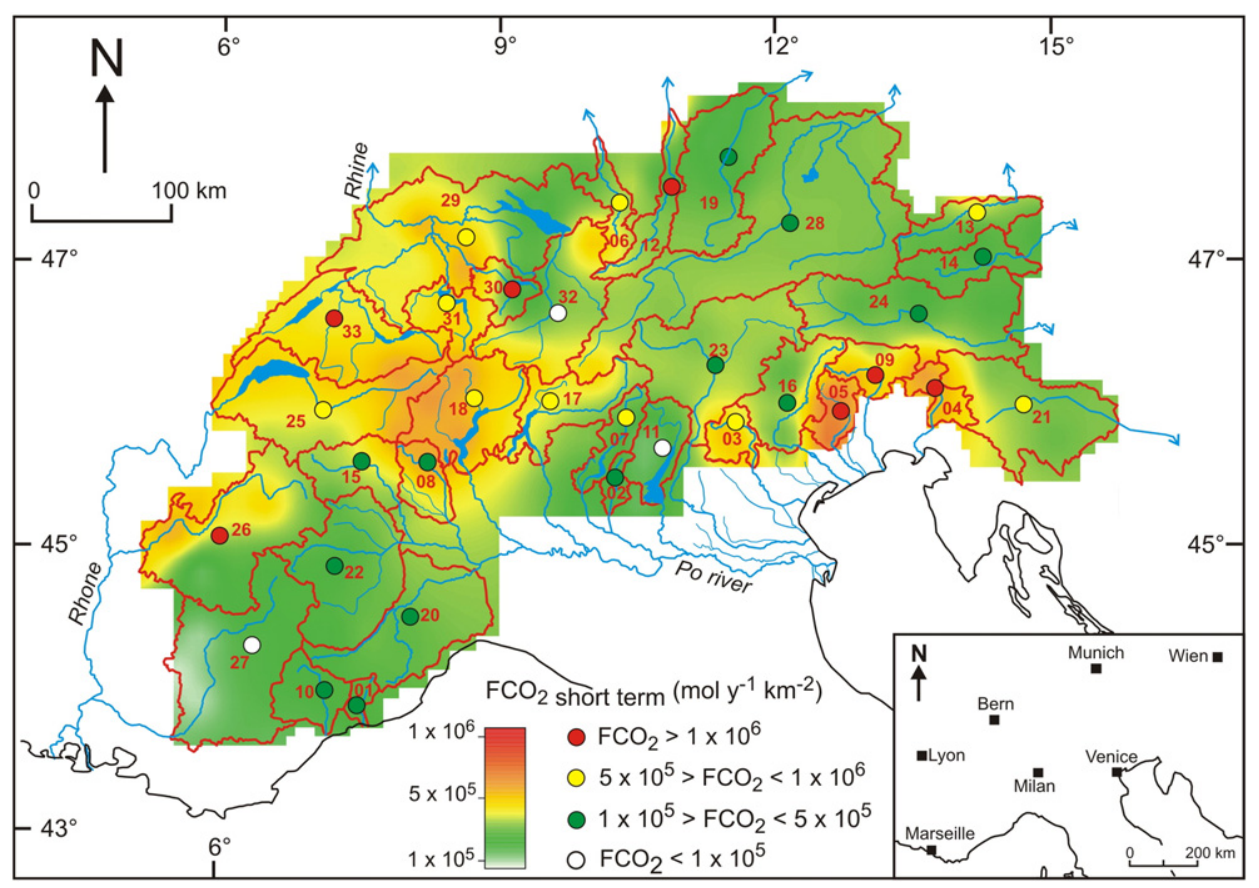

Fig. 12. Map of short-term carbon consumption in the Alps.

flux on a regular $50 \mathrm{~km} \times 50 \mathrm{~km}$ grid covering the whole study area $\left(223,613 \mathrm{~km}^{2}\right)$, basing on average runoff values, and we prepared a map showing the average $\mathrm{CO}_{2}$ consumption in the Alps (Fig. 12). The map, computed using the Sequential Gaussian Simulation method (Deutsch and Journel, 1988; Cardellini et al., 2003), reveals two areas with high $\mathrm{CO}_{2}$ consumption rates in the Alps: (i) a large area in the central-western Alps, including the Aare, Reuss, Ticino, and part of the Rhone, Isere, Linth and Rhine River basins, and (ii) an areas in eastern Alps encompassing the Livenza, Isonzo, and Tagliamento River basins. In the same map (Fig. 12), we show the values obtained using the geochemical model. It is noteworthy their good spatial correlation with the $F_{\mathrm{CO} 2 \text {-short }}$ values obtained by the regression model.

\section{Conclusions}

Estimation of $\mathrm{CO}_{2}$ consumption in the Alps is a good proxy for present day global $\mathrm{CO}_{2}$ consumption at mid latitudes, because lithology in the Alps approximates the average composition of the continental crust, and climate in the region is relatively stable compared to other regions at similar latitudes where extreme climatic events are more frequent.

The Alps are characterized by chemical weathering rates ranging over two orders of magnitude, with an average value of $83 \times 10^{3} \pm$ $16 \times 10^{3} \mathrm{~kg} \mathrm{~km}^{-2} \mathrm{y}^{-1}$. Considering the entire region, the chemical weathering process removes from the atmosphere/soil system $9.42 \times 10^{10} \pm 1.88 \times 10^{10} \mathrm{~mol} \mathrm{y}^{-1}$ of $\mathrm{CO}_{2}$, corresponding to an average $\mathrm{CO}_{2}$ flux per unit area of $5.03 \times 10^{5} \pm 1.00 \times 10^{5} \mathrm{~mol} \mathrm{~km}^{-2} \mathrm{y}^{-1}$. The value is higher, but of the same order of magnitude of the world average $\mathrm{CO}_{2}$ consumed by weathering $\left(2.46 \times 10^{5} \mathrm{~mol} \mathrm{~km}^{-2} \mathrm{y}^{-1}-\right.$ Gaillardet et al., 1999), close to the values estimated for the Amazon River $\left(2.71 \times 10^{5} \mathrm{~mol} \mathrm{~km}^{-2} \mathrm{y}^{-1}-\right.$ Amiotte-Suchet and Probst, 1993a; $3.11 \times 10^{5} \mathrm{~mol} \mathrm{~km}^{-2} \mathrm{y}^{-1}-$ Probst et al., 1994), and one order of magnitude higher than the estimates for the Congo River $\left(5.05 \times 10^{4} \mathrm{~mol} \mathrm{~km} \mathrm{k}^{-2} \mathrm{y}^{-1}-\right.$ Amiotte-Suchet and Probst, 1993b; $5.00 \times 10^{4} \mathrm{~mol} \mathrm{~km}^{-2} \mathrm{y}^{-1}-$ Probst et al., 1994). Our estimates are consistent with previous estimations in river basins with similar climatic conditions and latitudes, including the Garonne River, where a $\mathrm{CO}_{2}$ consumption of $2.24 \times 10^{5} \mathrm{mo} \mathrm{km}^{-2} \mathrm{y}^{-1}$ was estimated using a similar approach (Amiotte-Suchet and Probst, 1993a), and a consumption in the range $1.13 \times 10^{5} \mathrm{~mol} \mathrm{~km}^{-2} \mathrm{y}^{-1}$ (Semhi et al., 1993 ) to $4.41 \times 10^{5} \mathrm{~mol} \mathrm{~km}^{-2} \mathrm{y}^{-1}$ (Etchanchu and Probst, 1988) was estimated on the basis of $\mathrm{HCO}_{3}^{-}$river fluxes measurements.

Only a small part of the $\mathrm{CO}_{2}$ removed from the atmosphere/soil system is stored in the solid Earth system for a long-term (>1 Ma). According to our calculations, more than $95 \%$ of the $\mathrm{CO}_{2}$ consumed by chemical weathering is returned to the atmosphere within one million year, and the long-term $\mathrm{CO}_{2}$ flux $\left(\mathrm{F}_{\mathrm{CO} 2 \text {-long }}\right)$ is about $5 \%$ of the short-term $\mathrm{CO}_{2}$ flux $\left(F_{\mathrm{CO} 2 \text {-short }}\right)$. However, the $F_{\mathrm{CO} 2 \text {-long value }}$ must be considered just a rough (probably minimum) estimation of the actual value, because it was computed assuming that alkaline metals deriving from rock weathering are rapidly involved in the process of reverse weathering; and there are still large uncertainties on the magnitude and significance of reverse weathering process, carbonate dissolution driven by sulphide oxidation, hydrothermal alteration reactions in the ocean.

Determining what are the most important environmental and/or geologic factors affecting the extent of chemical weathering and $\mathrm{CO}_{2}$ consumption remains debated. Several works assert the pre-eminence of climatic factors, primarily temperature (e.g., Berner, 1994), but some case studies underscore the primary importance of bedrock lithology and other geologic factors in chemical weathering (e.g., Edmond and Huh, 1997).

In our study, the analysis of the controlling factors exhibits a correlation between $F_{\mathrm{CO} 2-\text { short }}$ weathering rates and runoff, indicating an important dependence of $\mathrm{CO}_{2}$ consumption on the intensity of the hydrological cycle, but also an indirect dependence on some geologic factors. In fact, runoff is given by the difference between precipitation, evaporation-transpiration (dependent on temperature), and infiltration, which depends on soil type, thickness, composition, permeability, and the degree of fracturing state of the parent bedrock.

On the contrary, the correlations of $F_{\mathrm{CO} 2 \text {-long }}$ with runoff and other controlling factors were weak or absent, because the main factors affecting $F_{\mathrm{CO} 2 \text {-long }}$ are external to the studied system (carbonate precipitation and eventually reverse weathering occur in the oceans).

The primary role of runoff as weathering controlling factor is in good agreement with previous findings by Amiotte-Suchet and Probst (1993b), (1995) and Kump et al. (2000). Depending both on climatic and geologic variables, runoff acts as a "summing factor", 
at least in climatically homogeneous regions like the Alps, and its role in modelling the short-term carbon cycle and climate should be carefully considered.

\section{Acknowledgements}

We would like to thank all the people and the institutions that made possible this work and two anonymous reviewers that significantly contributed to the overall quality of the manuscript.

For the laboratory analysis we are grateful to Fausto Matteucci and Gianluca Polidori of the Geochemical Laboratory of Perugia University, to Giovanni Chiodini and Stefano Caliro of the Geochemical Laboratory of Osservatorio Vesuviano - INGV of Napoli, to Marie José Tavella, Jonathan Prunier and Pierre Brunet of the laboratories of Midi-Pyrénées Observatory (OMP - Toulouse) and Ecolab (Laboratoire écologie fonctionnelle et environnement - Toulouse).

For the hydrological data we are grateful to Angela Sulis (ARPA Lombardia), to Alberto Deana, Ivano Di Fant and Andrea Marin (Regione Friuli Venezia Giulia), to Gianmarco Egiatti (ARPA Veneto), to Emanuela Bassi (ARPA Piemonte), to Tomislava Bošnjak (Meteorological and Hydrological Service, Croazia) and to the staff of the Ufficio Dighe Provincia di Trento.

For the fieldworks we are grateful to Keegan Alagna and Angela Baldini (Perugia University) and to Luca Delucchi (Fondazione Edmund Mach - Istituto Agrario di San Michele all'Adige).

\section{References}

Amiotte-Suchet, P., 1995. Cycle du carbone, érosion chimique des continents et transfert vers les océans. Sci. Géol. Mém. Strasbourg 97, 156.

Amiotte-Suchet, P., Probst, J.L., 1993a. Modelling of atmospheric $\mathrm{CO}_{2}$ consumption by chemical weathering of rocks: application to the Garonne, Congo and amazon basins. Chem. Geol. 107, 205-210.

Amiotte-Suchet, P., Probst, J.L., 1993b. Flux de $\mathrm{CO}_{2}$ consommé par altération chimique continentale: influences du drainage et de la lithologie. C. R. Acad. Sci. Paris II Méc. Phys. Chim. Astron. 317, 615-622.

Amiotte-Suchet, P., Probst, J.L., 1995. A global model for present day atmospheric $\mathrm{CO}_{2}$ consumption by chemical erosion of continental rocks $\left(\mathrm{GEM} \mathrm{CO}_{2}\right)$. Tellus 47, 273-280.

Amiotte-Suchet, P., Probst, J.L., 1996. Origines du carbone inorganique dissous dans les eaux de la Garonne: variation saisonnieres et interannuelles. Sci. Géol. Bull. Strasbourg 49, 101-126.

Amiotte-Suchet, P., Probst, J.L., Ludwig, W., 2003. Worldwide distribution of continental rock lithology: implications for the atmospheric/soil $\mathrm{CO}_{2}$ uptake by continental weathering and alkalinity river transport to the oceans. Glob. Biogeochem. Cycles 17, 1038. http://dx.doi.org/10.1029/2002GB001891.

Bard, A., Renarda, B., Langa, M., Giuntolia, I., Korckc, J., Koboltschnigd, G., Janžae, M., D'Amico, M., Volkeng, D., 2015. Trends in the hydrologic regime of Alpine rivers. J. Hydrol. http://dx.doi.org/10.1016/j.jhydrol.2015.07.052.

Basu, A., 1981. Weathering before the advent of land plants: evidence from unalterated detrital K-felspars in Cambrian-Ordovician arenites. Geology 9, 505-506.

Beaulieu, E., Goddéris, Y., Donnadieu, Y., Labat, D., Roelandt, C., 2012. High sensitivity of the $\mathrm{CO}_{2}$ sink by continental weathering to the future climate change. Nat. Clim. Chang. 2, 346-349. http://dx.doi.org/10.1038/nclimate1419.

Berner, R.A., 1991. A model for atmospheric $\mathrm{CO}_{2}$ over Phanerozoic Time. Am. J. Sci. 291 339-379.

Berner, R.A., 1994. Geocarb II: a revised model of atmospheric $\mathrm{CO}_{2}$ over Phanerozoic Time. Am. J. Sci. 294, 56-91.

Berner, R.A., 2003. The long-term carbon cycle, fossil fuels and atmospheric composition. Nature 426, 323-326.

Berner, R.A., 2004. The Phanerozoic Carbon Cycle: $\mathrm{CO}_{2}$ and $\mathrm{O}_{2}$. Oxford University Press, Oxford.

Berner, R.A., 2006. GEOCARBSULF: a combined model for Phanerozoic atmospheric $\mathrm{O}_{2}$ and $\mathrm{CO}_{2}$. Geochim. Cosmochim. Acta 70, 5653-5664. http://dx.doi.org/10.1016/j. gca.2005.11.032.

Berner, E.K., Berner, R.A., 1987. The Global Water Cycle. Geochemistry and Environment. Prentice Hall, Engelwood Cliffs, New Jersey.

Berner, E. K., Berner, R. A., Moulton, K.L., 2003. Plants and Mineral Weathering: Present and Past. In: Drever, J.I., (Ed.) Holland, H.D., Turekian, K.K., (Executive Eds.) Surface and Ground Water, Weathering, and Soils. Treatise on Geochemistry, Volume 5, Elsevier, p.169-188.

Berner, E.K., Berner, R.A., 2012. Global Environment: Water, air, and Geochemical Cycles. second edition. Princeton University Press, Princeton, New Jersey.

Berner, R.A., Lasaga, A.C., Garrels, R.M., 1983. The carbonate-silicate geochemical cycle and its effect on atmospheric carbon dioxide over the past 100 million years. Am. J. Sci. 283, 641-683.

Berner, R.A., Kothavala, Z., 2001. Geocarb III: a revised model of atmospheric $\mathrm{CO}_{2}$ over Phanerozoic time. Am. J. Sci. 301, 182-204.
Bluth, G.J.S., Kump, L.R., 1994. Lithological and climatological controls of river chemistry. Geochim. Cosmochim. Acta 58, 2341-2359.

Boeglin, J.L., Probst, J.L., 1998. Physical and chemical weathering rates and $\mathrm{CO}_{2}$ consumption, in a tropical lateritic environment: the upper Niger basin. Chem. Geol. 148, 137-156.

Brady, P.V., 1991. The effect of silicate weathering on global temperature and atmospheric $\mathrm{CO}_{2}$. J. Geophys. Res. Solid Earth 96 (B11), 18101-18106.

Brantley, S. L., 2003. Reaction kinetics of primary rock-forming minerals under ambient conditions. In: Drever, J.I., Holland, H.D., Turekian, K.K., Surface and ground water, weathering, and soils. treatise on geochemistry, 5, Elsevier, 73-117.

BGR (2011) Geologische Karte der Bundesrepublik Deutschland 1:1,000,000 (GK1000), BGR, Hannover.

Bricker, O.P., Jones, B.F., 2003. Mass-balance approach to interpreting weathering reactions in watershed systems. In: Drever, J.I., Holland, H.D., Turekian, K.K. Surface and Ground Water, Weathering, and Soils. Treatise on Geochemistry, 5, Elsevier, 119-132.

Brunetti, M., Maugeri, M., Monti, F., Nanni, T., 2006. Temperature and precipitation variability in Italy in the last two centuries from homogenised instrumental time sereis. Int. J. Climatol. 26, 345-381.

Cardellini, C., Chiodini, G., Frondini, F., 2003. Application of stochastic simulation to $\mathrm{CO}_{2}$ flux from soil: mapping and quantification of gas release. J. Geophys. Res. 2425. http://dx.doi.org/10.1029/2002JB002165.

C.N.R.-I.S.E. Sezione di Idrobiologia ed Ecologia delle Acque Interne, 2004I. Ricerche sull'evoluzione del lago Maggiore. Aspetti limnologici. Programma quinquennale 1998-2002. Campagna 2002. Commissione Internazionale per la protezione delle acque italo-svizzere (Ed.: 153 pp. http://www.cipais.org).

C.N.R.-I.S.E. Sede di Verbania, 2007. Ricerche sull'evoluzione del Lago Maggiore. Aspetti limnologici. Programma quinquennale 2003-2007. Campagna 2007 e Rapporto Quinquennale 2003-2007. Commissione Internazionale per la protezione delle acque italo- svizzere (Ed.: 132 pp. http://www.cipais.org)

C.N.R.-I.S.E. Sede di Verbania, 2013. Ricerche sull'evoluzione del Lago Maggiore. Aspetti limnologici. Programma quinquennale 2008-2012. Campagna 2012 e Rapporto Quinquennale. Commissione Internazionale per la protezione delle acque italosvizzere (Ed.: 133 pp. http://www.cipais.org).

Craig, H., 1961. Isotopic variations in meteoric waters. Science 133, 1702-1703.

Dal Piaz, G.V., Bistacchi, A., Massironi, M., 2003. Geological outline of the Alps. Episodes 26, 175-180.

Deutsch, C.V., Journel, A.G., 1998. GSLIB: Geostatistical Software Library and Users Guide. Applied Geostatistical Series. Oxford University Press, New York.

Dixon, J.L., Hartshorn, A.S., Heimsath, A.M., Di Biase, R.A., Whipple, K.X., 2012. Chemical weathering response to tectonic forcing: a soils perspective from the San Gabriel Mountains, California. Earth Planet. Sci. Lett. 323-324, 40-49. http://dx.doi.org/10. 1016/j.epsl.2012.01.010.

Drever, J.I., 1994. The effect of land plants on weathering rates of silicate minerals. Geochim. Cosmochim. Acta 58, 2325-2332.

Edmond, J.M., Huh, Y., 1997. Chemical weathering yields from basement and orogenic terrains in hot and cold climates. In: Ruddiman, W.F. (Ed.), Tectonic Uplift and Climate Change. Plenum Press, New York, pp. 329-351.

Egger, H., Krenmayr, H.G., Mandl, G.W., Matura, A., Nowotny, A., Pascher, G., Pestal, G. Pistotnik, J., Rockenschaub, M., Schnabel, W., 1999. Geological Map of Austria 1 2.000.000. Geologische Bundesanstalt, Wien, Austria.

Emerson, S.R., Hedges, J.I., 2008. Chemical Oceanography and the Marine Carbon Cycle. Cambridge University Press (462 pp.).

Etchanchu, D., Probst, J.L., 1988. Evolution of the chemical composition of the Garonne river water during the period 1971-1984. Hydrol. Sci. J. 33, 243-256.

Flintrop, C., Hohlmann, B., Jasper, T., Korte, C., Podlaha, O.G., Scheele, S., Veizer, J., 1996. Anatomy of pollution: rivers of North Rhine-Westphalia, Germany. Am. J. Sci. 296 59-98.

Fournier, F., 1960. Climat et Érosion. Presses Universitaries de France, Paris.

Frisch, R., 1979. Tectonic progradation and plate tectonic evolution of the Alps. Tectonophysics 60, 121-139.

Gaillardet, J., Dupré, B., Louvat, P., Allègre, C.J., 1999. Global silicate weathering and $\mathrm{CO}_{2}$ consumption rates deduced from the chemistry of large rivers. Chem. Geol. 159, 3-30.

Garrels, R.M., Mackenzie, F.T., 1971. Evolution of Sedimentary Rocks. Norton \& Co., New York.

Garzanti, E., Resentini, A., Vezzoli, G., Andò, S., Malusà, M.G., Padoan, M., Paparella, P., 2010. Detrital fingerprint of fossil continental-subduction zones (Axial Belt Provenance, European Alps). J. Geol. 118, 341-362.

Gislason, S.R., Arnorsson, S., Armansson, H., 1996. Chemical weathering of basalt in southwest Iceland: effects of runoff, age of rocks and vegetative/glacial cover. Am. J. Sci. 296, 837-907.

Gislason, S.R., Oelkers, E.H., 2011. Silicate rock weathering and the global carbon cycle. In: Harmon, R., Parker, A. (Eds.), Frontiers in Geochemistry: Contribution of Geochemistry to the Study of the Earth. Wiley-Blackwell (84-103 pp.).

Gurtz, J., Baltensweiler, A., Lang, H., 1999. Spatially distributed hydrotope-based modelling of evapotranspiration and runoff in mountainous basins. Hydrol. Process. 13, 2751-2768.

Haas, J., Kovacs, S., Krystin, L., Lein, R., 1995. Significance of Late Permian-Triassic facies zones in terrane reconstructions in the Alpine-North Pannonian Domain. Tectonophysics 242, 19-40.

Hartmann, J., Moosdorf, N., 2012. The new global lithological map database GLiM: a representation of rock properties at the Earth surface. Geochem. Geophys. Geosyst. 13, Q12004. http://dx.doi.org/10.1029/2012GC004370.

Holland, H.D., 1978. The Chemistry of the Atmosphere and Oceans. Wiley Interscience, New York.

Hren, M.T., Hilley, G.E., Page Chamberlain, C., 2007. The relationship between tectonic uplift and chemical weathering rates in the Washington cascades: field measurements 
and model predictions. Am. J. Sci. 307, 1041-1063. http://dx.doi.org/10.2475/09. 2007.01.

Huh, Y., 2010. Estimation of atmospheric $\mathrm{CO}_{2}$ uptake by silicate weathering in the Himalayas and the Tibetan Plateau: a review of existing fluvial geochemical data. Monsoon evolution and tectonics-climate linkage in Asia. Geol. Soc. Lond. Spec. Publ. 342, 129-151.

IAEA, 1981. Stable isotope hydrology. Deuterium and oxygen-18 in water cycle. In: Gat, J.R., Gonfiantini, R. (Eds.), Technical Report. International Atomic Energy Agency, Wien.

IUGS Subcommission on the systematics of the Igneous Rocks, 1973. Classification and nomenclature of the plutonic rocks. Neues Jahrb. Mineral. Monatshefte 149-164.

Le Bas, M.J., Le Maitre, R.W., Streckeisen, A., Zanettin, R., 1986. A chemical classification of volcanic rocks based on the total alkali-silica diagram. J. Petrol. 27 (3), 745-750.

Li, G., Elderfield, H., 2013. Evolution of carbon cycle over the past 100 million years. Geochim. Cosmochim. Acta 103, 11-25. http://dx.doi.org/10.1016/j.gca.2012.10.014.

Li, G., Ji, J., Chen, J., Kemp, D.B., 2009. Evolution of the Cenozoic carbon cycle: the roles of tectonics and $\mathrm{CO}_{2}$ fertilization. Glob. Biogeochem. Cycles 23, GB1009. http://dx.doi. org $/ 10.1029 / 2008 \mathrm{~GB} 003220$

Longinelli, A., Selmo, E., 2003. Isotopic composition of precipitation in Italy: a first overall map. J. Hydrol. 270, 75-88.

Louvat, P., Allègre, C.J., 1997. Present denudation rates at Réunion Island determined by river geochemistry: basalt weathering and mass budget between chemical and mechanical erosions. Geochim. Cosmochim. Acta 61, 3645-3669.

Knoll, M.A., James, W.C., 1987. Effect of the advent and diversification of vascular land plants on mineral weathering through geologic time. Geology 15, 1099-1102.

Kump, L.R., Brantley, S.L., Knoll, M.A., 2000. Chemical weathering, atmospheric $\mathrm{CO}_{2}$, and climate. Annu. Rev. Earth Planet. Sci. 28, 611-667. http://dx.doi.org/10.1146/ annurev.earth.28.1.611.

Kump, L.R., Kasting, J.F., Crane, R.G., 2009. The Earth System. 3rd edition. Prentice Hall (432 pp.).

Mackenzie, F.T., Garrels, R.M., 1966. Chemical mass balance between rivers and oceans. Am. J. Sci. 264, 507-525. http://dx.doi.org/10.2475/ajs.264.7.507.

Mackenzie, F.T., Kump, L.R., 1995. Reverse weathering, clay mineral formation, and oceanic element cycles. Science 270, 586-587. http://dx.doi.org/10.1126/science.270. 5236.586.

Marchina, C., Bianchini, G., Natali, C. Pennisi, M., Colombani, N., Tassinari, R., Knoeller, K. 2014. The Po river water from the Alps to the Adriatic Sea (Italy): new insights from geochemical and isotopic $\left(\delta^{18} \mathrm{O}-\delta \mathrm{D}\right)$ data. Environ. Sci. Pollut. Res. 22 (7), 5184-5203. http://dx.doi.org/10.1007/s11356-014-3750-6.

Meybeck, M., 1986. Composition chimique naturelle des ruisseaux non pollués en France. Sci. Géol. Bull. 39, 3-77.

Meybeck, M., 1987. Global chemical weathering of surficial rocks estimated from river dissolved load. Am. J. Sci. 287, 401-428.

Meybeck, M., 2003. Global occurrence of major elements in rivers. Surface and Ground Water, Weathering, and Soils. Treatise on Geochemistry, Volume 5. Editor: J.I. Drever. Executive Editors: H.D. Holland and K.K. Turekian. Elsevier, 207-224 p.

Michalopoulos, P., Aller, R.C., 1995. Rapid clay mineral formation in amazon delta sediments: reverse weathering and oceanic elemental cycles. Science 270, 614-617.

Michalopoulos, P., Aller, R.C., 2004. Early diagenesis of biogenic silica in the amazon delta: alteration, authigenic clay formation, and storage. Geochim. Cosmochim. Acta 68 1061-1085. http://dx.doi.org/10.1016/j.gca.2003.07.018.

Millot, R., Gaillardet, J., Dupré, B., Allègre, C.J., 2002. The global control of silicate weathering rates and the coupling with physical erosion: new insights from rivers of the Canadian Shield. Earth Planet. Sci. Lett. 196, 83-98.

Misra, S., Froelich, P.N., 2012. Lithium isotope history of cenozoic seawater: changes in silicate weathering and reverse weathering. Science 335, 818-823. http://dx.doi. org/10.1126/science.1214697.

Mitchell, T., Jones, P.D., 2005. An improved method of constructing a database of monthly climate observations and associated high-resolution grids. Int. J. Climatol. 25 693-712.

Mortatti, J., Probst, J.L., 2003. Silicate rock weathering and atmospheric/soil $\mathrm{CO}_{2}$ uptake in the Amazon Basin estimated from river water geochemistry: seasonal and spatial variations. Chem. Geol. 197, 177-196.

Mosello, R., Barbieri, A., Brizzio, M.C., Calderoni, A., Marchetto, A., Passera, S., Rogora, M., Tartari, G., 2001. Nitrogen budget of Lago Maggiore: the relative importance of atmospheric deposition and catchment sources. J. Limnol. 60 (1), 27-40.

Neteler, M., Mitasova, H., 2008. Open source GIS: a GRASS GIS approach. Third edition The International Series in Engineering and Computer Science vol. 773. Springer, New York (406 pp.).

Nisi, B., Vaselli, O., Buccianti, A., Minissale, A., Delgado Huertas, A., Tassi, F., Montegrossi, G., 2008. Geochemical and isotopic investigation of the dissolved load in the running waters from the Arno Valley: evaluation of the natural and anthropogenic input. Mem. Descrittive Carta Geol. Ital. LXXIX, 1-91.

Noh, H., Huh, Y., Qin, J., Ellis, A., 2009. Chemical weathering in the Three Rivers Region of eastern Tibet Geochim. Cosmochim. Acta 73, 1857-1877.

Olivier, J.-M., Carrel, G., Lamouroux, N., Dole-Olivier, M.-J., Mallard, F., Bravard, J.-P., Amoros, C., 2009. The Rhône River Basin. In: Tockner, K., Robinson, C. Uehlinger, U. (Eds.), Rivers of Europe. Academic Press, pp. 247-295.

Pearson, K., 1895. Notes on regression and inheritancein the case of two parents. Proc. R. Soc. Lond. 58, 240-242.

Peripoli, G., 2008. Chemical characterization of Adige River along longitudinal gradients Tesi di laurea. Università di Padova.

Pinet, P., Souriau, M., 1988. Continental erosion and large-scale relief. Tectonics 7, 563-582.
Probst, J.L., 1992. Géochimie de l'érosion continentale: mécanismes, bilance global actuel et fluctuations au cors des 500 dernier millions d'années. Sci. Géol. Mém. Strasbourg $94,161$.

Probst, J.L., Mortatti, J., Tardy, Y., 1994. Carbon river fluxes and global weathering $\mathrm{CO}_{2}$ consumption in the Congo and Amazon River Basins. Appl. Geochem. 9, 1-13.

Quantum GIS Development Team, 2012. Quantum GIS geographic information system. Open source geospatial foundation project. http://qgis.osgeo.org.

R Core Team, 2015. R: a language and environment for statistical computing. R Foundation for Statistical Computing, Vienna, Austria (URL http://www.R-project.org/).

Rogora, M., Mosello, R., Arisci, S., Brizzio, M., Barbieri, A., Balestrini, R., Waldner, P., Schmitt, M., Stähli, M., Thimonier, A., Kalina, M.., Puxbaum, H., Nickus, U., Ulrich, E. Probst, A., 2006. Atmospheric deposition on the Alps: effects on the functioning of the alpine and subalpine ecosystems. Hydrobiologia 562, 17-40.

Roy, S., Gaillardet, J., Allègre, C.J., 1999. Geochemistry of dissolved and suspended loads of the Seine river, France: anthropogenic impact, carbonate and silicate weathering. Geochim. Cosmochim. Acta 63, 1277-1292.

Schmid, S.M., Fügenschuh, B., Kissling, E., Schuster, R., 2004. Tectonic map and overall architecture of the Alline orogen. Eclogae Geol. Helv. 97, 93-117.

Schwartzman, D.W., Volk, T., 1989. Biotic enhanchement of weathering and habitability of earth. Nature 340, 457-460.

Semhi, K., Probst, J.L., Etcheber, H., Bazerbachi, A., 1993. Dissolved river transport in the Garonne Basin, seasonal and interannual variations. EUG VII, Strasbourg. Abstract supplement n.1 to Terra Nova 5, p. 633.

Sillen, L.G., 1967. The ocean as a chemical system. Science 156, 1189-1197.

Spearman, C., 1904. The proof and measurement of association between two things. Am. J. Psychol. 15, 72-101.

Stampfly, G., Mosar, J., Favre, P., Pillevuit, A., Vannay, J.C., 2001. Permo-Mesozoic Evolution of the Western Tethys Realm: the Neo-Tethys East Mediterranean Basin Connection. Peri-Tethys Memoir 6: Peri-Tethyan Rift/Wrench Basins and Passive Margins. Mém. Mus. Natn. Hist. Nat. Paris 51, pp. 108-186.

Stefanini, S., 1976. Composizione delle acque fluviali del Friuli-Venezia Giulia durante la fase di magra e di piena dei corsi d'acqua. Quad. Ist. Ric. Sulle Acque 28, 386-450.

Tachikawa, T., Kaku, M., Iwasaki, A., 2011. ASTER GDEM Version 2 Validation Report. Report to the ASTER GDEM Version 2 Validation Team.

Tardy, Y., 1986. Le cycle de l'eau. Climats, Paléoclimates et Géochimie Globale. Masson,

Tipper, E.T., Bickle, M.J., Galy, A., West, A.J., Pomiés, C., Chapman, H.J., 2006. The short-term climatic sensitivity of carbonate and silicate weathering fluxes: insight from seasonal variations in river chemistry. Geochim. Cosmochim. Acta 70, 2737-2754. http://dx. doi.org/10.1016/j.gca.2006.03.005.

Torres, M.A., West, A.J., Li, G., 2014. Sulphide oxidation and carbonate dissolution as a source of $\mathrm{CO}_{2}$ over geological timescales. Nature 507, 346-349.

Tricart, P., 1984. From passive margin to continental collision: a tectonic scenario for the Western Alps. Am. J. Sci. 284, 97-120

Trümphy, R., 1960. Paleotectonic evolution of the Central and Western Alps. Bull. Geol. Soc. Am. 71, 843-908.

Uehlinger, U., Wantzen, K.M., Leuven, R.S.E.W., Arndt, H., 2009. The Rhine River Basin. In: Tockner, K., Robinson, C., Uehlinger, U. (Eds.), Rivers of Europe. Academic Press, pp. $199-245$

Velbel, M.A., 1993. Temperature dependence of silicate weathering in nature: how strong of a negative feed Back on long-term accumulation of atmospheric $\mathrm{CO}_{2}$ and global greenhouse warning? Geology 21, 1059-1062.

Verbunt, M., Gurtz, J., Kasper, K., Lang, H., Warmerdam, P., Zappa, M., 2003. The hydrological role of snow and glaciers in alpine river basins and their distributed modeling. J. Hydrol. 282, 36-55.

Viers, J., Oliva, P., Dandurand, J.L., Dupré, B., Gaillardet, J., 2007. Chemical weathering rates, $\mathrm{CO}_{2}$ consumption, and control parameters deduced from the chemical composition of rivers. In: Surface and Ground Water, Weathering, and Soils. Treatise on Geochemistry, Volume 5. Editor: J.I. Drever. Executive Editors: H.D. Holland and K.K. Turekian. Elsevier, p. 1-25.

Viviroli, D., Weingartner, R., 2004. The hydrological significance of mountains: from regional to global scale. Hydrol. Earth Syst. Sci. 8, 1016-1029.

Walker, J.C.G., Hayes, P.B., Kasting, J.F., 1981. A negative feedback mechanism for the longterm stabilization of the earth's surface temperature. J. Geophys. Res, 86, 9776-9782.

Weingartner, R., Viviroli, D., Schädler, B., 2007. Water resources in mountain regions: a methodological approach to assess the water balance in a highland-lowland system. Hydrol. Process. 21, 578-585.

White, A.F., 2003. Natural weathering rates of silicate minerals. Surface and Ground Water, Weathering, and Soils. Treatise on Geochemistry, Volume 5. Editor: J.I. Drever. Executive Editors: H.D. Holland and K.K. Turekian. Elsevier, p. 133-168.

White, A.F., Blum, A.E., 1995. Effects of climate on chemical weathering in watersheds. Geochim. Cosmochim. Acta 59, 1729-1747.

Yang, C.K., Telmer, K., Veizer, J., 1996. Chemical dynamics of the 'St. Lawrence' riverine system; $\delta \mathrm{D}_{\mathrm{H} 2 \mathrm{O}}, \delta^{18} \mathrm{O}, \delta \mathrm{C}_{\mathrm{dic}}, \delta^{34} \mathrm{~S}_{\text {sulfate }}$ and dissolved ${ }^{87} \mathrm{Sr} /{ }^{86} \mathrm{Sr}$. Geochim. Cosmochim. Acta 60, 851-866

\section{Web references}

http://www.swisstopo.admin.ch - 18.03.2105

http://one.geology.cz/ - 18.03.2105

http://www.isprambiente.gov.it - 18.03.2105 